\title{
ONE DECADE OF INFLATION TARGETING IN THE WORLD: WHAT DO WE KNOW AND WHAT DO WE NEED TO KNOW?
}

\author{
Frederic S. Mishkin \\ Klaus Schmidt-Hebbel \\ Working Paper 8397 \\ http://www.nber.org/papers/w8397 \\ NATIONAL BUREAU OF ECONOMIC RESEARCH \\ 1050 Massachusetts Avenue \\ Cambridge, MA 02138 \\ July 2001
}

We thank Mark Stone for excellent comments, as well as Ben Bernanke, Bennett McCallum, and other participants at the Central Bank of Chile Conference on "Ten Years of Inflation Targeting: Design, Performance, Challenges" (Nov. 2000) for insightful discussion. We are also grateful to Verónica Mies for outstanding research assistance. The views and conclusions presented do not necessarily reflect the position of Columbia University, the National Bureau of Economic Research or the Central Bank of Chile.The views expressed herein are those of the authors and not necessarily those of the National Bureau of Economic Research.

(C) 2001 by Frederic S. Mishkin and Klaus Schmidt-Hebbel. All rights reserved. Short sections of text, not to exceed two paragraphs, may be quoted without explicit permission provided that full credit, including $\odot$ notice, is given to the source. 
One Decade of Inflation Targeting in the World:

What Do We Know and What Do We Need to Know?

Frederic S. Mishkin and Klaus Schmidt-Hebbel

NBER Working Paper No. 8397

July 2001

JEL No. E52, E51, E31

\begin{abstract}
$\underline{\text { ABSTRACT }}$
One decade of inflation targeting in the world offers lessons on the design and implementation of inflation targeting, the conduct of monetary policy, and country performance under inflation targeting. This paper reviews briefly the main design features of 18 inflation targeting experiences, analyzes statistically if countries under inflation targeting are structurally different from non-inflation targeting industrial countries, and reviews existing evidence about the success of inflation targeting. The interaction of inflation targeting design features and the conduct of monetary policy during transition to low inflation are tackled next. The paper ends by focusing on unresolved issues on design and implementation of inflation targeting and their relation to the conduct of monetary policy - open issues that have to be addressed in the next decade of inflation targeting.
\end{abstract}

Frederic S. Mishkin

Graduate School of Business

Uris Hall 619

Columbia University

New York, NY 10027

and NBER

fsm3@columbia.edu
Klaus Schmidt-Hebbel

Central Bank of Chile

Agustinas 1180

Santiago, Chile

kschmidt@bcentral.cl 


\section{Introduction}

The emergence of inflation targeting over the last ten years has been an exciting development in the approach of central banks to the conduct of monetary policy. After initial adoption by New Zealand in 1990, inflation targeting has been the choice of a growing number of central banks in industrial and emerging economies, and many more are considering future adoption of this new new monetary framework.

One decade of inflation targeting in the world offers lessons on the design and implementation of inflation targeting, the conduct of monetary policy, and country performance under inflation targeting. In section 2, this paper reviews briefly the main design features of 18 inflation targeting experiences, analyzes statistically if countries under inflation targeting are structurally different from non-inflation targeting industrial countries, and reviews existing evidence about the success of inflation targeting. The interaction of inflation targeting design features and the conduct of monetary policy during transition to low inflation are tackled in section 3. Then the paper focuses on unresolved issues on design and implementation of inflation targeting and their relation to the conduct of monetary policy (section 4). Brief conclusions close the paper.

\section{What Do We Know about Inflation Targeting after a Decade of World Experience?}

\subsection{Who does inflation targeting and how?}

Inflation targeting started a decade ago, with public announcements of inflation targets in New Zealand and Chile. According to our count, 19 inflation targeting country cases have been recorded as of November 2000. They include a variety of experiences that comprise industrial and emerging economies, transition and steady-state inflation targeters, semi and full-fledged targeters, old and recent starters, and current and former targeters. ${ }^{1}$

\footnotetext{
${ }^{1}$ Classifying country cases into inflation targeting and other monetary regimes involves subjective choices for two reasons. First, there is lack of full agreement on the main conditions and features of inflation targeting and how they apply during transition to low inflation - an issue that we discuss below. Second, some countries have used simultaneously inflation targets and other nominal anchors (the exchange rate and/or a monetary aggregate), particularly at their early years of inflation targeting. IMF (2000), Mahadeva and Sterne (2000), and Sterne (2000) discuss and present comprehensive country classifications of monetary regimes. Reflecting different classification criteria, recent cross-country studies of IT experiences differ in their country samples - e.g. Bernanke, Laubach, Mishkin, and Posen (1999), Schaechter, Stone, and Zelmer (2000), Corbo, Landerretche, and Schmidt-Hebbel (2001), and Corbo and Schmidt-Hebbel (2000).
} 
Figure 1 depicts adoption dates and initial inflation rates (at year of adoption) for the 19country sample. ${ }^{2}$

We introduce two country groups for carrying out our empirical analysis conducted for the decade of the 1990s (Table 1) - a sample of inflation targeters and a control group of non-targeters. The first sample of inflation targeters (labeled inflation targeters) is comprised by a heterogeneous group of 18 industrial and emerging economies: Australia, Brazil, Canada, Chile, Colombia, Czech Republic, Finland, Israel, Korea, Mexico, New Zealand, Peru, Poland, South Africa, Spain, Sweden, Thailand, and the United Kingdom (Finland and Spain dropped out of this group when relinquishing monetary policy at adoption of the euro in 1999). ${ }^{3}$

The second sample is a control group of 9 industrial economies that were not inflation targeters during the 1990s: Denmark, France, Germany, Italy, Japan, Norway, Portugal, Switzerland, and the US. Among these are two countries (Germany and Switzerland) that had explicit monetary targets in place during most of the $1990 \mathrm{~s}^{4}$ could be classified as implicit inflation targeters (as argued by Bernanke, Laubach, Mishkin and Posen, 1999), two countries without explicit targets (Japan and the U.S.), and the remaining 5 European countries that targeted their exchange rate to the deutschmark before adopting the euro in $1999 .^{5}$

Inflation targeters exhibit some commonalities and many differences in inflation targeting preconditions, target design, and operational features. Four stylized facts emerge from country experiences and features, as summarized in Table 2.

\footnotetext{
${ }^{2}$ Starting dates are defined by the first month of the first period for which inflation targets have been announced previously. For example, the starting date for Chile is January 1991 (the first month of calendar year 1991, for which the first inflation target was announced in Sep. 1990). The initial inflation level is defined as the year-on-year CPI inflation rate of the last quarter before the first month of inflation targeting (for example, the fourth quarter of 1990 in the case of Chile).

${ }^{3}$ The number of inflation targeters, eighteen is one less than the nineteen in Figure 1 and Table 2 because Switzerland was not an inflation targeter in the 1990s.

${ }^{4}$ Germany adopted the euro in early 1999 and Switzerland adopted inflation targeting in 2000.

${ }^{5}$ The use of this control group of high-income industrial economies with alternative monetary frameworks in place reflects our objective to link adoption of inflation targeting with structural features, observed in the world sample of 18 industrial and higher middle-income countries. By defining a control group of highperforming economies with similar features to those that have adopted inflation targeting makes it statistically more difficult to identify significant determinants of the choice of inflation targeting than if we had chosen a control group including developing-country non-inflation targeters.
} 
(i) Full-fledged inflation targeting is based on five pillars: absence of other nominal anchors, an institutional commitment to price stability, absence of fiscal dominance, policy instrument independence, and policy transparency and accountability. While pillars 2 to 5 are requirements for effective conduct of monetary policy under any regime, they are particularly important prerequisites for effective policy under inflation targeting. The reason is that the success of inflation targeting depends so strongly on high market credibility in the central bank's resolve and ability to put into place policies geared at meeting the target. And credibility is fostered by the five institutional pillars.

(ii) Inflation adoption ranges from evolutionary to revolutionary. Many countries have adopted inflation targeting without satisfying one or more of the above mentioned conditions. For example, Chile and Israel targeted the exchange rate during most of the 1990s (Israel still does it today). The Bank of England started inflation targeting well before attaining instrument independence. Most countries adopted inflation targeting well before achieving high levels of policy transparency (including publication of inflation reports, inflation projections, and monetary policy meeting minutes) and full accountability. Some countries - including Colombia, Israel, Korea, Mexico, Peru, and South Africa - do not publish inflation forecasts yet. On the other extreme is Brazil, who adopted full-fledged inflation targeting right from the start.

Country experience suggests that adoption of inflation targeting during the 1990s has been equivalent to a monetary policy learning process. Only by now there is a broad consensus about the conditions that should be in place for effective full-fledged inflation targeting. However these prerequisites were less obvious in the first half of the 1990s, when early inflation targeters perfected their framework by learning from their own and the other inflation targeters' cumulative experience.

(iii) Inflation ranges from moderately high to very low at inflation targeting adoption dates. Some countries adopted inflation targeting when their inflation rates were well above steady-state levels, using inflation targeting as the main device to build up credibility, bring down inflation expectations, and pursue a path of convergence to low and stationary inflation. This is the case of early emerging-country inflation targeters that 
started at initial inflation rates of $15-45 \%$ (Chile, Israel, Peru) and subsequent emergingcountry adopters where initial inflation was in the range of 7-20\% (Czech Republic, Colombia, Mexico, Poland). This stands in contrast to all industrial-country and some emerging-country inflation targeters that started at initial inflation close to stationary low levels.

Multi-year transitions toward steady-state inflation pose serious challenges and difficulties to inflation targeting, including the need for announcing annual inflation targets (that are much harder to meet) under conditions of high inflation expectations and limited policy credibility. We postpone discussion of the issues related to transition to low inflation to section 3 below.

(iv) Inflation targeters vary widely regarding inflation targeting implementation features, including target price index, target width, target horizon, escape clauses, accountability of target misses, goal independence, and overall transparency and accountability regarding conduct of policy under inflation targeting. Some of these differences can be attributed to country variation in institutions and history; other reflect the differences between inflation targeting in transition toward and at low inflation (as discussed below). Moreover, some differences of inflation targeting design features also reflect different views among policy makers and academics about how monetary policy under inflation targeting should be conducted in conditions of low inflation.

\subsection{Are inflation targeters different?}

Are countries that adopt inflation targeting different from industrial non-inflation targeters regarding structural conditions and macroeconomic performance? Here we tackle this question by comparing our sample of 18 inflation targeters to the control group of 9 industrial non-targeters defined above. We focus on the relation between having (or not) an inflation targeting framework in place and a set of structural, institutional, and macroeconomic features. The empirical analysis here is necessarily preliminary because (as discussed in footnote 1) it is not always easy to decide whether a country should be 
classified as engaging in inflation targeting or not. ${ }^{6}$ Furthermore, determining the exact date of adoption of an inflation-targeting regime is often quite difficult. Officials at many central banks we have consulted often give dates for the adoption of inflation targeting that are earlier than outsiders do (e.g., Bernanke et al., 1999). The uncertainty of dating often follows from the fact that inflation targeting is adopted gradually over time, making the exact date of adoption difficult to determine.

Our data set is comprised by annual variables for 27 countries and 10 years (19901999) of data. The focus is on the discrete inflation targeting regime variable that takes a value of 1 (when an inflation targeting regime is in place) or 0 (when an alternative monetary regime is in place) and a set of variables that could be associated with the choice of an inflation targeting regime. ${ }^{7}$ The latter variables include measures of the use of alternative nominal anchors (a measure of exchange-rate band width and a monetary target dummy), structural conditions (trade openness), central bank independence measures (formal independence, instrument independence, and goal independence), and macroeconomic variables (the inflation rate and the fiscal surplus ratio to GDP).

Table 3 reports cross-country and panel statistics and correlations for inflation targeting and related variables. The data reflect large variation in all variable categories across countries and over time in our 27-country sample. Panel correlations are sometimes very different from cross-country correlations, including cases of changes in signs. This is a likely result of the noise encountered in annual country data - hence we focus on crosscountry correlations.

Having inflation targeting in place is positively and significantly correlated with no individual variable and negatively and significantly correlated only with monetary growth targets $(M T)$. Inflation targeting is positively and not significantly correlated with trade openness (Open), the fiscal surplus ratio to GDP (Fiscal), exchange rate band width $(B W)$, and central-bank instrument independence $(C B I I)$, and negatively and not significantly

\footnotetext{
${ }^{6}$ For example, although the central banks of Peru and Colombia do announce inflation targets, their monetary policy frameworks do not contain many crucial features of an inflation targeting regime (Mishkin and Savastano, 2000). Korea is classified as an inflation targeter because it does have an announced inflation target, and yet it appears to have been pursuing a de facto exchange rate peg in the first two years of its inflation targeting regime, which is inconsistent with an inflation targeting regime. Note that if we drop these three countries from the sample the empirical results reported above are not appreciably affected.

${ }^{7}$ Similar definitions are used for other discrete variables used here (see the Data Appendix for variable definitions and sources).
} 
correlated with normalized inflation (Inf), central bank formal independence $(C B F I)$, and central-bank goal independence $(C B G I){ }^{8}$.

Next we introduce a multivariate probit model for the likelihood of having an inflation-targeting regime in place, based on the observation of the variables identified above. The model specifies the probability of having an inflation targeting regime in place $(\operatorname{Pr}(I T \mid \ldots)$ as a function of the variables introduced above:

$$
\operatorname{Pr}(I T \mid \ldots)=\mathrm{f}(\text { Inf,, Open, Fiscal, BW, MT, CBFI, CBGI, CBII ) }
$$

Expected coefficient signs are positive for Fiscal, $B W$, and the three measures of central-bank independence, negative for $M T$, and ambiguous for Inf and Open.

Before turning to the results we note that caution should be exercised in the causal interpretation of equation (1). While certain structural features may be exogenous to the choice of inflation targeting, it is very likely that adoption of inflation targeting requires and hence contributes to - renouncing the use of other nominal targets, improving macro performance (such as reducing inflation and improving the fiscal stance), and strengthening central bank independence, as we argue below. Hence potential reverse causation should lead to careful interpretation of the empirical results.

Noisy results for the full panel probit regression led us to report cross-country results only, based on country decade-averages for each variable, including the dependent variable, i.e., the inflation-targeting regime choice. We start by discussing the full-sample results in the first column of Table 4.

Inflation targeting is positively and significantly associated with the level of (normalized) inflation, a result that reflects that inflation targeting has been adopted by countries that, on average, have exhibited higher levels of inflation than industrial noninflation targeters have. Indeed, most emerging countries have adopted inflation targeting as a device to bring inflation down to low single-digit levels. And most inflation targeters both emerging and industrial-country targeters - made major progress in reducing inflation

${ }^{8}$ There are only a few large positive or negative correlations among variables other than inflation targeting. Exceptions are the three measures of central-bank independence, which are highly and positively correlated with each other. 
during or shortly before or after adopting inflation targeting (Bernanke et al. 1999, Corbo et al. 2000). Countries that trade relatively more (because they are more open and/or smaller than non-inflation targeters) are significantly more likely to adopt inflation targeting - a result that reflects that most large industrial countries are not inflation targeters.

Inflation targeting is negatively associated with the fiscal surplus ratio to GDP, again a result that follows from having a control group of non-inflation targeters comprised by 9 industrial countries that, on average, show a stronger fiscal position than the 18 inflation targeters. However, this association does not attain conventional significance levels.

Inflation targeting is positively but not significantly associated to the width of exchange rate band. As expected, inflation targeting is negatively and significantly associated to the adoption of monetary growth targets, reflecting the incompatibility of having simultaneously in place explicit monetary and inflation targets.

Finally let's consider the influence of central-bank independence. The likelihood of having inflation targeting in place is positively associated to central-bank formal independence (although its coefficient is not significant at conventional levels) and significantly to central-bank instrument independence. However inflation targeting is negatively and significantly associated with central-bank goal independence. The latter result suggests that central banks - when they have the freedom to determine their target levels - are more likely to do so under exchange rate or monetary-growth anchors than when they adopt inflation targets. Hence inflation targeting is associated with surrendering goal independence to governments. We report in column 2 a regression that drops the less significant variables. All five remaining regressors become more significant.

The preceeding results are based on the full country sample, that includes three countries with very high inflation rates in the early 1990s - Brazil, Peru, and Poland. Dropping the three latter from the sample yields regression results for a restricted 24country sample, reported in columns 3 and 4 of Table 4 . Coefficient signs, values, and significance levels change little from those reported for the full sample. Hence our results are robust to exclusion of high-inflation outliers. 
Performing one more robustness test, we drop Colombia, Korea, and Peru from the sample. As discussed in footnote 5, there are some questions about whether these three countries should be classified as inflation targeters. The regression results for this alternative 24-country sample, reported in columns 5 and 6 of Table 4, also confirm our full-sample results.

\section{$\underline{2.3 \text { Is inflation targeting a success story? }}$}

On one hand it has been argued that structural features and macroeconomic performance of inflation-targeting countries differ in some respects from those of countries that have adopted alternative monetary frameworks (i.e., Bernanke, et al., 1999, Cecchetti and Ehrmann 2000, Schaechter, Stone, and Zelmer 2000, Corbo and Schmidt-Hebbel 2000, Corbo, Landerretche, and Schmidt-Hebbel 2000). On the other hand, it has been argued that some industrial countries without formal inflation targets (like Germany before the euro, Switzerland before 2000, and the U.S.) pursue a monetary policy that is close to explicit inflation targeting (Mishkin 1999b). Would this imply that inflation targeting is observationally equivalent to alternative monetary frameworks regarding the conduct of policy and its results? What does a review of the recent empirical literature tell about this issue?

We focus on this question by conducting a brief review of recent empirical work evaluating a decade of worldwide experience with inflation targeting. Far from attempting a comprehensive evaluation, we identify a few selective and tentative conclusions that provide a partial view of the relative success of inflation targeting. ${ }^{9}$

\section{Central bank independence is mutually reinforced with inflation targeting. Country} experience during the 1990s suggests that extending larger degrees of independence to central banks often supports adoption of inflation targeting. In some countries inflation targeting was adopted after granting formal and instrument independence to central banks, as was the case in New Zealand and Chile. In other countries, like the UK, instrument

\footnotetext{
${ }^{9}$ A methodological point is in order. We should keep in mind that inferences about inflation targeters' success are still highly tentative, in view of the ambiguities surrounding the sample definitions for inflation-targeting countries, the possible systemic equivalence of some features of inflation targeting with those of alternative
} 
independence came after inflation targeting. The positive association has been confirmed by our empirical results for formal and instrument independence, but not for goal independence.

Communication, transparency, and accountability are mutually reinforced with inflation targeting. Adoption of inflation targeting has typically been followed (and sometimes preceded) by major improvement in central bank communication with the public and the markets and significant upgrade in monetary policy transparency. Most inflation targeters have started publication of inflation reports, monetary policy statements, centralbank board meeting minutes, central-bank models, and inflation forecasts (see Table 2). This major communication effort conducted by central banks is arguably more important under inflation targeting than under alternative monetary regimes, considering the central role played by policy credibility and inflation expectations in attaining inflation targets (Bernanke et al. 1999).

Inflation targeting has been successful in helping countries to reduce inflation - but not below levels of industrial non-inflation targeters. The evidence shows that countries that have adopted inflation targeting reduce their long-run inflation below the levels they would have attained in the absence of inflation targeting. However inflation targeting does not yield inflation below the levels attained by industrial countries that have adopted other monetary regimes, as shown by Bernanke et al. 1999 and our own results above. Adoption of inflation targeting is typically associated to a major upfront investment in inflation reduction (Corbo et al. 2000).

Inflation targeting has been tested favorably by adverse shocks. The 1990s, except for emerging-country financial crises in 1997-99, have been very favorable to the world economy, led by the largest post-WWII U.S. expansion. This fact has led many observers to argue that inflation targeting is a yet untested framework, as no major adverse shocks have put strain on the achievement of low and stable inflation in many inflation targeters. But

monetary regimes, the relevant counterfactual, potential selection bias, and mutual causation of inflationtargeting adoption and country performance. 
this is incorrect. Many inflation targeters are small open economies that have been subject to severe shocks in the aftermath of the 1997 Asian crisis - as opposed to the large industrial non-inflation targeters that have been unaffected by these shocks. The combined adverse financial and terms-of-trade shocks suffered by Australia, Chile, Israel, and New Zealand, among other inflation targeters, have led to major exchange rate devaluation in these countries, testing significantly the attainment of their inflation targets. They weathered this storm successfully, by recording little passthrough from devaluation to inflation. The 1999-2000 oil price shock represented the second test for oil-importing inflation targeters, including the above mentioned countries and Brazil, the Czech Republic, and Poland, among others. Significant increases in imported inflation - through both energy prices and exchange-rate devaluation - could put in jeopardy these countries' targets. However current casual evidence from many inflation targeters suggests that the effects of the oil shock on core inflation have been minor, while only temporary and modest increases in headline inflation are observed.

Inflation targeting has helped in reducing sacrifice ratios and output volatility in countries that have adopted inflation targeting, to levels close to those in industrial non-inflation targeters. Bernanke et al. (1999) found that inflation targeting did not make disinflation less costly, as sacrifice ratios and Phillips curves had not been altered by inflation targeting. However, based on new evidence for a larger sample of inflation targeters and non inflation targeters, Corbo et al. (2000) conclude that sacrifice ratios have declined in emerging countries after adoption of inflation targeting. They also find that output volatility has fallen in both emerging and industrialized economies after adopting inflation targeting, to levels that are similar to (and sometimes lower than) those observed in industrial countries that do not target inflation.

\section{Inflation targeting may have helped in bringing down and guiding inflation} expectations and dealing better with inflation shocks. According to Almeida and Goodhart (1998) and Bernanke et al. (1999), inflation targeting has not reduced inflation expectations quickly, only gradually over time. Corbo et al. (2000) report that inflation forecast errors, based on country VAR models, have fallen consistently with adoption of 
inflation targeting, toward the low levels prevalent in non-targeting industrial countries. They also find that inflation persistence has declined strongly among targeters during the 1990s, suggesting that inflation targets have strengthened forward-looking expectations on inflation, hence weakening the weight of past inflation.

Monetary policy under inflation targeting is flexible inasmuch it responds symmetrically to inflation shocks and does accommodate temporary inflation shocks that do not affect the medium-term attainment of the target. Inflation targeters are not "inflation nutters" (a phrase due to King, 1996) because they typically react symmetrically to positive and negative shocks, pursue disinflation gradually, and react to temporary output shocks. Evidence by Cecchetti and Ehrmann (2000) shows that output deviations have a positive weight in all objective functions of inflation targeters.

Monetary policy is more clearly focused on inflation under inflation targeting and may have been toughened by inflation targeting. Central-bank mandates to focus on price stability tend to be strengthened by inflation targeting (Bernanke et al. 1999). Cecchetti and Ehrmann (2000) have provided evidence that central-bank aversion to inflation shocks (relative to output shocks) has been toughened with the adoption of inflation targeting, a conclusion partly confirmed by Corbo et al. (2000).

We conclude that inflation targeting has proven to be a very successful new monetary framework, both in comparison to inflation targeters' preceding experience and relative to alternative monetary regimes adopted by a control group of highly successful industrial countries that had in place other monetary arrangements during the 1990s.

\section{Error! Bookmark not defined. Revisiting Operational Design Issues}

Our survey in the previous section outlines some elements of the operational design of inflation targeting regimes. However, there are three design issues that deserve detailed

discussion: 1) the interaction of length of the target horizon, the width of the target range, and the use of escape clauses; 2) inflation targeting during the transition from high to low inflation; 
3) who should set the medium-term inflation target; and 4) the role of the exchange rate and other asset prices. We discuss each of these in turn.

\subsection{Interaction of the Target Horizon, Width of Target Range, Escape Clauses, and Choice of}

\section{Core Inflation Targets}

A central problem for the design of inflation targeting regimes is that monetary policy affects the economy and inflation with long lags. For countries that already have achieved low inflation, the lags are estimated to be quite extended - two years or even longer. Yet shorter time horizons, specifically annual inflation targets, have been quite common in inflation targeting regimes.

The use of too short a time horizon, particularly when the range of an inflation target is narrow, can lead to a controllability problem - too frequent misses of the inflation target even when monetary policy is being conducted optimally. For example, exactly this occurred in New Zealand in 1995, when the Reserve Bank overshot its one-year-horizon inflation target range of 0 to $2 \%$ by a few tenths of a percentage point. This overshoot made the governor subject to dismissal under the central banking law, even though it was widely recognized that the overshoot was likely to be short-lived and that inflation would soon fall, as it later did. Although in the New Zealand case the breach of the inflation target range did not result in a substantial loss of credibility, in other circumstances (or for an emerging market country), this could result in a serious loss of credibility for the central bank.

Too short a horizon and a narrow target range can also lead to instrument instability, in which excessive swings in the monetary policy instruments occur when the central bank tries to hit the inflation target. This problem can be especially serious in a small, open economy where a short horizon and narrow range results in greater reliance on manipulating the exchange rate to achieve the inflation target because exchange rate movements have a faster impact on inflation than interest rates. The annual target in New Zealand and the 2 percentage point range for the inflation target was an important reason why the Reserve Bank focused more on exchange rates in the conduct of monetary policy. This resulted in overly tight monetary policy at the end of 1996, with the overnight cash rate going to $10 \%$ because of fears that inflation would rise above the target range in 1997. 
The example of New Zealand in 1996 also illustrates that too short a horizon and too narrow a range can also induce undesired output fluctuations. A consequence of the overly tight monetary policy at the end of 1996 was that it contributed to the recession in 1997 and 1998, which was made worse by the negative terms-of-trade shock resulting from the East Asian crisis.

To avoid controllability and instrument instability problems in an inflation-targeting regime, there are four routes that central banks can take. First, they can build in formal escape clauses in their inflation-targeting regime to allow for misses of the inflation target under particular circumstances. Second, they can target core inflation rather than headline inflation. Third, they can widen the range of the inflation target. Fourth, they can set inflation targets for several years ahead.

Only New Zealand has put formal escape clauses into its inflation targeting regime by allowing for misses of the inflation target range when there are significant changes in the terms of trade, changes in indirect taxes that affect the price level, and supply shocks such as a major livestock epidemic. Note that the New Zealand escape clauses are designed to deal with supply shocks only because they are the only shocks that can be readily identified as being exogenous. Aggregate demand shocks may be exogenous, but are just as likely to be induced by monetary policy. Thus allowing central banks to appeal to them to justify misses of an inflation target would be likely to destroy central bank credibility and undermine the inflation targeting regime. Thus formal escape clauses, although providing some increased flexibility, are only able to partially cope with the controllability and instrument instability problems from too short a horizon and too narrow a target range.

An alternative to escape clauses as a method of coping with supply shocks is to target a core-type inflation measure, which excludes items from the price index such as food and energy that are especially subject to supply shocks. Use of a core inflation measure has the advantage over escape clauses that it involves no discretion after a supply shock occurs which might cause the public to question the central bank's honest commitment to achieving the inflation targets. Instead, which items are to be excluded from the construction of the inflation measure are decided on ex ante. It is probably why core measures of inflation as targets have been used more widely than escape clauses. 
However, targeting on core inflation measures also shares with escape clauses the disadvantage that it only deals with instrument instability and controllability problems arising from supply shocks and not from aggregate demand shocks. Furthermore, core inflation measures have the disadvantage that they are not as well understood by the public as headline inflation measures, thus making core inflation targets a somewhat weaker communication vehicle than headline inflation targets. In addition, core inflation measures exclude items that consumers care a lot about, particularly poorer ones for which food and energy form a larger share of their budget. If these items are excluded from the inflation measure a central bank targets, the central bank may be subjected to criticisms that it does not care sufficiently about poorer members in the society.

Widening the target range, by itself, is also not a solution to controllability and instrument instability problems. Estimates of the irreducible uncertainty around an inflation target with a one-year horizon are on the order of 5 percentage points (e.g., Haldane and Salmon 1995, and Stevens and Debelle 1995), although over time, success with inflation targeting might decrease the volatility of inflation expectations and hence inflation. Choosing such a wide range on the inflation target is highly problematic because it will likely confuse the public about the central bank's intentions, and the resulting high ceiling for the range is likely to make the commitment to low inflation less clear cut, thereby reducing the credibility of monetary policy. This type of problem actually occurred in the United Kingdom in 1995, when inflation exceeded the target midpoint of $2.5 \%$ by over one percentage point, but without breaching the $4 \%$ ceiling, thus giving the Chancellor of the Exchequer cover to resist the Bank of England's recommendation for tightening of monetary policy (see Bernanke et al. 1999).

Lengthening the target horizon to correspond more closely to the lags of monetary policy effects on inflation would seem to be the best solution to the controllability and instrument instability problems. Indeed, given the problems it encountered in 1997 and 1998, the Reserve Bank of New Zealand now emphasizes a target horizon of six to eight quarters in their discussion of monetary policy (see Sherwin 1999, and Drew and Orr 1999). Other central banks, including the Bank of Canada and the Bank of England, have for a long time, emphasized a target horizon of closer to two years, and this has recently become a feature of the Chilean targeting regime (Central Bank of Chile, 2000a.) 
However, as Svensson (1997) has emphasized, if central banks are concerned about output fluctuations (i.e., put a weight on output fluctuations in their loss function), then the inflation forecast should approach the long-run inflation target gradually over time. This implies that a horizon even longer than the policy lags might be appropriate for the inflation target. Such a long horizon for the inflation target may create problems for an inflation targeting regime because the long period before there is verification of hitting the target may weaken credibility, particularly if credibility of the central bank is not high to begin with. One possible way to deal with this is to recognize that there is an interaction between the optimal horizon and range for the target: the target horizon could be kept relatively short, say two years, if the target range is widened. Indeed, widening of the target range from 2 to 3 percentage points is now seen by the Reserve Bank of New Zealand to have improved the inflation-targeting regime, even though the Bank was initially not a supporter of this change. However, widening the target range is not without its problems, as mentioned above, because it can also increase confusion and weaken the credibility of the targeting regime. ${ }^{10}$

Another way to allow for longer horizons is the use of multi-year annual targets so that the path of the inflation target can approach the long-run inflation goal more gradually. This is the strategy that has recently been adopted by both Brazil and Mexico (Bank of Brazil, 1999, and Bank of Mexico 2000). An alternative approach is for the central bank to continue to announce only one medium-term inflation target, but to also announce a long-run target with a specified date as to when it should be achieved. A third alternative for the central bank is to announce only one long-term inflation target and to publish inflation forecasts for future years, thus describing the expected path of inflation toward the long-run target. This is the approach that has been recently adopted by Chile (Central Bank of Chile, 2000b), following other industrial countries.

\footnotetext{
${ }^{10}$ Indeed, one of the authors of this paper has argued elsewhere (Mishkin, 2000a) that a point target for inflation may be more desirable than a target range because edges of the target range can take on a life of their own. With target ranges in place, politicians, financial markets and the public often focus on whether inflation is just outside or inside the edge of a range, rather than on the magnitude of the deviation from the midpoint. As discussed above, the opposite problem occurred in the United Kingdom in 1995 when inflation exceeded the target midpoint by over one percentage point, but without breaching the upper band. The problem with too much focus on the edges of the range is that it can lead the central bank to concentrate too much on keeping the inflation rate just within the bands rather than trying to hit the midpoint of the range. It is difficult to imagine a sensible objective function for policymakers that would justify such asymmetric reactions to inflation rates just inside and outside the bands.
} 


\section{$\underline{3.2 \text { Inflation Targeting During the Transition from High to Low Inflation }}$}

When inflation is initially well above the long-run inflation goal consistent with price stability, the credibility of the central bank is likely to be low. In addition, at initially high inflation rates (say over 10\%), inflation is not easily controlled by the monetary authorities. Thus inflation targeting to achieve a disinflation from a high inflation rate faces extra challenges.

One way to deal with the complications arising from an initially high inflation is to phase in inflation targeting gradually, making it more formal with increasing success on the disinflation front, as suggested by Masson et al. (1997). This is exactly the strategy that has been pursued by emerging market countries with initially high inflation (Mishkin, 2000b, and Mishkin and Savastano 2000). ${ }^{11}$ For example, when Chile adopted inflation targeting in 1991 with inflation exceeding $20 \%$, the inflation target was treated more as an official inflation projection rather than as a formal "hard" target (Morandé and Schmidt-Hebbel 1997, 2000, Morandé 2001). Over time, the central bank put greater emphasis on the price stability objective and with its success in both disinflating and meeting its inflation objectives, the public began to interpret those objectives as "hard" targets for which the central bank could be made accountable. Finally in May of 2000, the Central Bank of Chile began to issue an inflation report-type document, with all the bells and whistles seen in similar documents in industrialized countries. For example, this Monetary Policy Report not only outlines developments on the inflation front and how the Bank intends to achieve its inflation target, but also includes inflation and output forecasts, along with confidence intervals for these forecasts displayed in the famous "fan" charts pioneered by the Bank of England.

Mexico also has been following a gradual approach to implementing inflation targeting. Senior officials of the Bank of Mexico recently characterized Mexico's monetary policy framework as being in "a transition period towards a clear-cut inflation targeting scheme" (Carstens and Werner 1999). For a number of years Mexico has made public an explicit inflation objective at the time the Minister of Finance submitted to Congress the government's economic program for the following year. The Bank of Mexico has increasingly put an emphasis on the inflation goal as the central objective of its monetary policy. In 1999,

\footnotetext{
${ }^{11}$ It has even been a feature of the adoption strategy of industrialized countries, who adopted inflation targeting when inflation has been at rates less than 10\% (Bernanke et al. 1999).
} 
after annual inflation at $12.3 \%$ fell below the $13 \%$ target, for the first time the central bank announced the $10 \%$ inflation target for the year 2000 before the Ministry of Finance submitted to Congress the economic program for the year. Starting in April of 2000, the Bank of Mexico has been issuing an Inflation Report, which documents what has been happening on the inflation front and how the Bank of Mexico intends to achieve its inflation objectives, but does not provide inflation and output forecasts. In its third Inflation Report, published in October 2000, the Bank of Mexico announced multi-year, annual targets, which converge to a long-run target of $3 \%$ to be reached by December 2003.

Weak credibility when inflation is initially high makes it more likely that the public and markets may not believe that the central bank is serious about hitting its targets if verification has to wait for more than one year in the future. This problem may make it very difficult for a central bank adopting inflation targeting when inflation is high to choose inflation targets with horizons longer than a year. As we have seen in the previous subsection, this presents the central bank with a dilemma because the lags from monetary policy to inflation are likely to be longer than a one-year horizon. A solution to this dilemma is to specify a path for the inflation target with multi-year targets, which is what the central banks of Brazil, Czech Republic, Mexico, and Poland have done since 1998. However, specifying a multi-year path for the annual inflation targets create the danger that even though a central bank is making good progress toward its long-run inflation goal, given the greater uncertainty of inflation control at high inflation rates it might still deviate substantially from the multi-year path. This problem can help explain why the Chilean central bank chose not to specify multiyear inflation targets when it embarked on its inflation-targeting regime in 1990.

When transiting from high to low inflation, there appears to be a stronger rationale for adopting a wider range for inflation targets to reflect the substantial uncertainty of inflation control when inflation is initially high. However, as discussed in the previous subsection, a wide range for the inflation target can lead to credibility problems because the government may be willing to advocate that all is well on the inflation front when the inflation rate is substantially above the midpoint of the target range, but is still below the ceiling of the range. A point target, on the other hand, makes this behavior on the part of the government less likely. Making sure that the government does not weaken the commitment to lowering inflation is especially important for inflation targeting regimes when inflation is high because 
credibility is so much more precarious in these situations. There is therefore a stronger argument for choosing a point target over a target range in an inflation-targeting regime during the transition from high to low inflation. Interestingly, the Central Bank of Chile switched from target ranges to point inflation targets in 1994 in the process of hardening its inflationtargeting regime.

Imperfect credibility during transition from moderately high to low inflation implies that inflation expectations are more geared to (higher) past inflation than to (lower) official inflation targets. Hence inflation inertia is potentially larger and rapid disinflation is potentially more costly in transition toward low inflation. Evidence for Chile, based on counterfactual simulations carried out by Corbo et al. (2001) and Morandé (2001), suggest that a quicker pace of disinflation toward the long-term $2-4 \%$ target would have involved a larger output sacrifice.

As is argued in Mishkin (2000c), an emphasis on avoiding undershoots of the inflation target is likely to improve the performance of inflation targeting regimes. When inflation approaches levels that are consistent with price stability, a symmetric approach to inflation targeting, in which undershoots are to be avoided just as stongly as overshoots, makes output declines and deflation less likely, and it also indicates that the central bank appropriately cares about output fluctuations, helping to maintain support for its independence. However, weak credibility when inflation targeting is adopted at relatively high inflation rates, which is often the situation for emerging market countries adopting inflation targeting, provides an argument for why an asymmetric approach to inflation targeting at higher inflation rates may have some advantages. Overshoots of inflation targets when inflation is still high may create fears that monetary policy is going back to its old, high-inflation, ways and overshoots could thus have devastating effects on central bank credibility. At high inflation, the central bank may therefore want to be particularly aggressive if it thinks there is a possibility that inflation will overshoot the target. This bias to preventing overshoots of the target necessarily implies that the central bank's preferences would be somewhat asymmetric, with overshoots receiving a greater weight in the loss function than undershoots. For example, the behavior of the Bank of Israel in recent years seems to be consistent with asymmetric preferences of this type. 
However asymmetric preferences can be taken too far. If the central bank is not sufficiently concerned about undershoots of the targets, it can produce greater uncertainty about inflation which interferes with private sector planning. Also, not avoiding undershoots of the target can lead to sharp declines in aggregate output which can not only be harmful to the economy, but can also lead to decreased public support for the central bank and the inflation targeting regime. Even if asymmetric preferences which stress avoiding overshoots more than undershoots of inflation targets make sense at high inflation rates, once the transition from high to low inflation is complete, they are no longer appropriate.

\subsection{Who Should Set the Medium-Term Inflation Target?}

Debelle and Fischer (1994) and Fischer (1994) make the useful distinction between goal independence, in which the central bank sets the goals of monetary policy, and instrument independence, in which the central bank controls monetary policy instruments. Instrument independence for central banks is supported by the need to insulate the central bank from short-run political pressures that may lead it to pursue time-inconsistent, expansionary policy that produces bad long-run outcomes. However, the argument that a central bank's long-run preferences should coincide with society's preferences, suggests that a central bank should be goal dependent. Having the government decide on the long-run inflation target for the central bank thus receives a lot of support.

Whether the government should set the medium-term inflation target rather than the central bank is a trickier question. If inflation is currently low, the medium-term target is likely to be the same as the long-run target and so there is no conflict between them, making it easier to make the case that the government should set the medium-term target, as it does in many inflation targeting regimes. However, if inflation is currently far from the long-run target, who sets the medium-term target is more complicated. The length of the lags from monetary policy to inflation is a technical issue that the central bank is far more qualified to determine than politicians. Thus how long it should take for inflation to return to the long-run target necessarily requires judgement about these lags which should be insulated from short-term political pressure if time-inconsistent policies are to be avoided. This argues for having the 
central bank set the medium-term inflation target because how quickly it approaches the longrun target reflects the lags of monetary policy effects on inflation.

On the other hand, as Svensson (1997) has shown, preferences on the weight given to minimizing output fluctuations relative to inflation fluctuations affects the speed at which inflation should be adjusted toward the long-run goal. Thus if the government's long-run preferences are to be reflected in monetary policy, there is an argument for the government having a role in setting the medium-term target because this determines the speed of convergence of inflation to the long-run target.

Clearly, there is a tradeoff on who should set medium-term inflation targets when inflation is far from the long-run goal. The argument for instrument independence suggests that the central bank should set the medium-term target, while the argument for goal dependence suggests that the government should set the medium-term target. For industrial countries, this may not be that much of a dilemma because medium-term targets and long-run targets are likely to be quite close. But for countries in the transition from high to low inflation, it is far less obvious that the government should determine the medium-term inflation target.

\subsection{The Role of the Exchange Rate and Other Asset Prices}

Movements of the exchange rate are clearly a major concern of central banks in inflation targeting as well as non-inflation targeting countries. Changes in the exchange rate can have a major impact on inflation, particularly in small, open economies. For example, depreciations lead to a rise in inflation as a result of the pass through from higher import prices and greater demand for exports, particularly in a small, open economy. In addition, the public and politicians pay attention to the exchange rate and this puts pressure on the central bank to alter monetary policy. An appreciation of the domestic currency can make domestic business uncompetitive, while a depreciation is often seen as a signal of failure of the central bank, as has recently been the case for the European Central Bank, even if this view is an unfair one.

Emerging market countries, quite correctly, have an even greater concern about exchange rate movements. Not only can a real appreciation make domestic industries less competitive, but it can lead to large current account deficits which can make the country more vulnerable to currency crisis if capital inflows turn to outflows. Depreciations in emerging 
market countries are particularly dangerous because they can trigger a financial crisis along the lines suggested in Mishkin (1996a, 1999a). These countries have much of their debt denominated in foreign currency and when the currency depreciates, this increases the debt burden of domestic firms. Since assets are typically denominated in domestic currency and so do not increase in value, there is a resulting decline in net worth. This deterioration in balance sheets then increases adverse selection and moral hazard problems, which leads to financial instability and a sharp decline in investment and economic activity. This mechanism explains why the currency crises in Mexico in 1994-95 and East Asia in 1997 pushed these countries into full-fledged financial crises, which had devastating effects on their economies.

The fact that exchange rate fluctuations are a major concern in so many countries raises the danger that monetary policy, even under an inflation-targeting regime, may put too much focus on limiting exchange rate movements. The first problem with a focus on limiting exchange rate movements is that it runs the risk of transforming the exchange rate into a nominal anchor that takes precedence over the inflation target. For example, as part of its inflation targeting regime, Israel had an intermediate target of a quite narrow exchange rate band around a crawling peg, whose rate of crawl was set in a forward-looking manner by deriving it from the inflation target for the coming year. Even though the Bank of Israel downplayed the exchange rate target relative to the inflation target over time, it did slow the Bank's efforts to win support for disinflation and lowering of the inflation targets (see Bernanke et al., 1999).

The second problem from a focus on limiting exchange rate fluctuations is that the impact of changes in exchange rates on inflation and output can differ substantially depending on the nature of the shock that causes the exchange rate movement. Different monetary policy responses are thus needed depending on the nature of the shock. If the domestic currency depreciates because of a pure portfolio shock, inflation is likely to rise and the appropriate response to keep inflation under control is for the monetary authorities to tighten monetary policy and raise interest rates. If the depreciation occurs in an emerging market country which has a substantial amount of foreign-denominated debt, tightening monetary policy to prevent a sharp depreciation may be even more necessary to avoid financial instability (for the reasons mentioned above). On the other hand, if the exchange rate depreciation occurs because of real shocks, the impact is less likely to be inflationary and a different monetary policy response is 
warranted, but even here it depends on the nature of the shock. A negative terms-of-trade shock, which lowers demand for exports, reduces aggregate demand and is thus likely to be deflationary. In this situation, the correct interest rate response is to lower interest rates to counteract the drop in aggregate demand, and not to raise interest rates. If the negative termsof-trade shock instead is due to a rise in import prices, there is a negative income effect, which could be offset by lowering interest rates. But there is also a direct inflationary effect, particularly if there is high indexation and pass-through that might suggest that interest rates should rise in order to prevent second-round effects.

One graphic example of where a focus on limiting exchange rate fluctuations helped induce the wrong policy response occurred in New Zealand in 1997 and 1998. As was mentioned above, the short horizon for the inflation target in New Zealand led the Reserve Bank to focus on the exchange rate as an indicator of the monetary policy stance because of the direct impact of exchange rate movements on inflation. By early 1997, the Reserve Bank institutionalized this focus by adopting as its primary indicator of monetary policy a Monetary Conditions Index (MCI) similar to that developed by the Bank of Canada. The idea behind the MCI, which is a weighted average of the exchange rate and a short-term interest rate, is that both interest rates and exchange rates on average have offsetting impacts on inflation on the assumption that portfolio shocks dominate exchange rate movements. With the negative terms of trade shock in 1997, the adoption of the MCI in 1997 led to a questionable monetary policy response to the East Asian crisis. With depreciation setting in after the crisis began in July 1997 after the devaluation of the Thai baht, the MCI began a sharp decline, indicating that the Reserve Bank needed to raise interest rates, which it did by over 200 basis points. The result was very tight monetary policy, with the overnight cash rate exceeding 9\% by June of 1998 . Because the depreciation was due to a substantial negative terms of trade shock which decreased aggregate demand, the tightening of monetary policy, not surprisingly, led to a recession and an undershoot of the inflation target range with actual deflation occurring in 1999. ${ }^{12}$ The Reserve Bank of New Zealand did eventually reverse its course, sharply lowering interest rates beginning in July 1998 after the economy had entered a recession. It also

\footnotetext{
${ }^{12}$ The terms of trade shock, however, was not the only negative shock the New Zealand economy faced during that period. Its farm sector experienced a severe drought which also hurt the economy. Thus a mistake in monetary policy was not the only source of the recession. Bad luck played a role too. See Drew and Orr (1999) and Brash (2000).
} 
recognized the problems with using an MCI as an indicator of monetary policy and abandoned it in 1999. Now the Reserve Bank operates monetary policy in a more conventional way, using the overnight cash rate as its policy instrument, with far less emphasis on the exchange rate in its monetary policy decisions.

Another example in where exchange rate fluctuations were limited was the case of Chile in 1998. At that time Chile's inflation targeting regime also included a focus on limiting exchange rate fluctuations by having an exchange rate band with a crawling peg which was (loosely) tied to lagged domestic inflation. In response to the combined financial and terms-oftrade shock due to the Asian crisis, the Central Bank of Chile adopted a stringent monetary policy and a defense of the peso with a narrowing of the exchange rate band and intervention in the foreign exchange market. When the economy entered into a mild recession in late 1998, the tight monetary policy was reversed when interest rates were lowered and the peso was allowed to decline. The exchange rate band was abolished in September 1999 and the peso floats freely since then.

The contrast of the experience of New Zealand and Chile during this period with Australia, another small open economy with an inflation-targeting regime, is revealing. Prior to adoption of its inflation-targeting regime in 1994, the Reserve Bank of Australia had adopted a policy of allowing the exchange rate to fluctuate without interference, particularly if the source of the exchange rate change was a real shock, like a terms of trade shock. Thus when faced with the devaluation in Thailand in July 1997, the Reserve Bank recognized that it would face a substantial negative terms of trade shock because of the large component of its foreign trade conducted with the Asian region and that it should not fight the depreciation of the Australian dollar that would inevitably result. ${ }^{13}$ Thus in contrast to New Zealand, it immediately lowered the overnight cash rate by 50 basis points to $5 \%$ and kept it near at this level until the end of 1998, when it was lowered again by another 25 basis points.

Indeed, the adoption of the inflation-targeting regime probably helped the Reserve Bank of Australia to be even more aggressive in its easing in response to the East Asian crisis and helps explain why their response was so rapid. The Reserve Bank was able to make clear that easing was exactly what inflation targeting called for in order to prevent an undershooting

\footnotetext{
${ }^{13}$ See McFarlane (1999) and Stevens (1999).
} 
of the target, so that the easing was unlikely to have an adverse effect on inflation expectations. The outcome of the Reserve Bank's policy actions was extremely favorable. In contrast to New Zealand and Chile, real output growth remained strong throughout this period. Furthermore, there were no negative consequences for inflation despite the substantial depreciation of the Australian dollar against the U.S. dollar by close to $20 \%$ : inflation remained under control, actually falling during this period to end up slightly under the target range of 2 to $3 \%$.

The discussion above therefore suggests that targeting on an exchange rate is likely to worsen the performance of monetary policy. This, however, does not imply that central banks should pay no attention to the exchange rate. An important transmission mechanism for monetary policy is the exchange rate and its level has important effects on inflation and aggregate demand depending on the nature of the shocks, particularly in small, open economies. Therefore, the control of inflation and aggregate demand requires the monitoring of exchange rate developments and the factoring of them into decisions on setting monetary policy instruments. A depreciation of the exchange rate due to portfolio shocks requires a tightening of monetary policy in order to keep inflation from rising. On the other hand, a depreciation from a negative terms of trade shock - when due to falling export prices requires a different response, an easing of monetary policy as Australia did in 1997.

There is another reason for central banks not to pursue a benign neglect of exchange rates, an issue that is particularly relevant for emerging market countries, as is emphasized in Mishkin (2000b) and Mishkin and Savastano (2000). For the reasons discussed earlier, emerging market countries with large foreign-denominated debt may not be able to afford sharp depreciations of their currencies, which can destroy balance sheets and trigger a financial crisis. Central banks in these countries may thus have to smooth "excessive" exchange rate fluctuations, but would not involve attempting to prevent the exchange rate from reaching its market-determined level over longer horizons. Exchange rate smoothing via foreign exchange market interventions might be necessary at times because of the possibility that such interventions can prevent dynamics in the micro structure of this market that may lead to exchange rate fluctuations that are divorced from fundamentals. However, continuing exchange market interventions, particularly unsterilized ones, are likely to be counterproductive because they are not transparent. Instead, exchange rate smoothing via 
changes in the interest rate instrument will be more transparent and indicate that the nominal anchor continues to be the inflation target and not the exchange rate. Central banks can also explain to the public the rationale for exchange rate intervention in a manner analogous to that for interest-rate smoothing, i.e., as a policy aimed not at resisting market-determined movements in an asset price, but at mitigating potentially destabilizing effects of abrupt and sustained changes in that price.

The conclusion that targeting on the exchange rate is likely to worsen the performance of monetary policy also applies to targeting other asset prices. Clearly, setting monetary policy instruments to achieve inflation targets requires factoring in asset price movements. Changes in asset prices like those on common stock, housing or long-term bonds have important effects on aggregate demand and inflation and are important transmission mechanisms for monetary policy (e.g., Mishkin 1996b). However, the response to fluctuations in these asset prices cannot be mechanical because, depending on the nature of the shocks driving these asset prices, optimal monetary policy responds in different ways. Furthermore, because many asset prices matter, targeting on just one would be suboptimal.

It is also highly problematic for a central bank to target variables that are hard to control - and clearly asset prices such as housing and stock prices fall into this category. Central banks often look foolish if they act to control asset prices and then are unable to do so. Furthermore, when central banks act as if they can control asset prices like those on common stocks, the public often begins to fear that central banks may be too powerful, thus potentially causing the public to question support for central bank independence. Some researchers (e.g., Cecchetti, Genberg, Lipsky, and Wadwani 2000) have suggested that the monetary authorities should act to limit asset price bubbles to preserve financial stability, but to do this successfully the monetary authorities need to know what are appropriate asset values. To think that government officials, even if they are central bankers, know better what the asset prices should be than private markets, who have stronger incentives to get things right, is, to say the least, highly presumptuous. Furthermore, as pointed out in Bernanke and Gertler (1999), an inflation targeting approach which does not target asset prices, but makes use of an informationinclusive strategy in setting policy instruments, does have the ability to make asset price bubbles less likely, thereby promoting financial stability. 
The bottom line is that the optimal conduct of monetary policy requires that many asset prices, whether exchange rates, stock prices, housing prices, and long-term bond prices, be factored into decisions about the setting of monetary policy instruments. Yet doing so is completely consistent with inflation targeting, which is an information inclusive strategy for the conduct of monetary policy. Targeting asset prices is, on the other hand, likely to lead to serious mistakes in monetary policy, and may weaken not only the commitment to the inflation target as a nominal anchor, but also the support for central bank independence.

\section{Some Unresolved Issues}

Inflation targeting regimes are continually evolving as experience and new research suggests better ways to conduct monetary policy. Two unresolved issues central to inflation targeting regimes, which are currently high on the research agenda of monetary economists, are: 1) what is the optimal long-run inflation goal?, and 2) would the price level be better to target rather than inflation?

\section{$\underline{4.1 \text { Long-Run Inflation Goal }}$}

A key question for any central bank using an inflation targeting strategy is what the long-run goal for inflation should be. Much research finds that there is a negative relationship between inflation and economic growth, ${ }^{14}$ but as pointed out in Bruno and Easterly (1996), the evidence for this negative relationship is weak at low inflation rates.

Because the empirical evidence on the direct relationship between inflation and growth is unlikely to help discriminate between different long-run goals which are less than $10 \%$, another approach to deciding on the appropriate long-run inflation target is to ask the deeper question of what does price stability mean? Alan Greenspan has provided a widely-cited definition of price stability: a rate of inflation that is sufficiently low that households and businesses do not have to take it into account in making everyday decisions. This definition of price stability is a reasonable one and, operationally, any inflation number between 0 and 3\% seems to meet this criterion. Some economists, Martin Feldstein (1997) and William Poole

\footnotetext{
${ }^{14}$ E.g., see Kormendi and Meguire (198), Grier and Tullock (1989), Cozier and Selody (1992), Fischer (1993), Anderson and Gruen (1995), Barro (1995), and Andres and Hernando (1999).
} 
(1999) being prominent examples, argue for a long-run inflation goal of $0 \%$, which has the psychological appeal of the "magic number" of zero. Indeed one concern is that an inflation goal greater than zero might lead to a decline in central bank credibility and instability in inflation expectations, which could lead to an upward creep in inflation. However, evidence in Bernanke et al. (1999) suggests that maintaining a target for inflation above zero, but not too far above (less than 3\%), for an extended period, does not lead to instability in the public's inflation expectations or to a decline in central bank credibility.

One prominent argument against setting the long-run inflation target above zero, raised by Akerlof, Dickens and Perry (1996), is that setting inflation at too low a level produces inefficiency and will result in a higher natural rate of unemployment. They argue that downward rigidity of nominal wages, which they say is consistent with the evidence, indicates that reductions of real wages can occur only through inflation. The implication is that a very low rate of inflation might prevent real wages from adjusting downward in response to declining labor demand in certain industries or regions, thereby leading to increased unemployment and hindering the re-allocation of labor from declining sectors to expanding sectors.

The evidence for the Akerlof-Dickens-Perry mechanism through which low inflation raises the natural rate of unemployment is not at all clear cut. Carruth and Oswald (1989), Ingrams (1991), McLaughlin (1994), and Yates (1995) find little evidence for downward nominal rigidities in wages in the United States and the United Kingdom. Also as pointed out by Groshen and Schweitzer (1996, 1999), inflation not only can put "grease" in the labor markets and allow downward shifts in real wages in response to a decline in demand along the lines of Akerlof, Dickens and Perry (1996), but can also put in "sand" by increasing the noise in relative real wages. This noise reduces the information content of nominal wages and hence the efficiency of the process by which workers are allocated across occupations and industries.

A more persuasive argument for a long-run inflation goal above zero is that it makes it less likely that the economy will experience episodes of deflation. A key factor that is found to promote episodes of financial instability in industrial countries is deflation (Mishkin 1991, 1997). Because debt contracts in industrialized countries frequently have long maturities, a deflation leads to an increase in the real indebtedness of firms and households, which leads to a decline in net worth and a deterioration in their balance sheets. Irving Fisher (1933) named 
this phenomenon "debt deflation" (but which might be more accurately referred to as "debt inflation in real terms through deflation") and saw it as a major factor promoting the economic downturn during the Great Depression. ${ }^{15}$ With less net worth, adverse selection and moral hazard problems increase for lenders and so they cut back on lending. The decline in net worth leads to a decline in the amount of collateral a lender can grab if the borrower's investments turn sour, and the reduction in collateral therefore increases the consequences of adverse selection because in the case of a default losses from loans are likely to be more severe. In addition, the decline in net worth increases moral hazard incentives for borrowers to take on excessive risk because they now have less to lose if their investments go sour. This reasoning indicates that deflation can promote financial instability in industrialized countries through the debt-deflation mechanism, a recent example of which is what has happened in Japan in the last decade (Mishkin 1998 and Bernanke 1999).

Another reason for choosing an inflation goal that makes deflation unlikely is that deflation may make it more difficult to conduct monetary policy. With more frequent periods of deflation resulting from too low a level of the inflation target, it will become more common that short-term interest rates will hit a floor of zero during deflations, as occurred during the Great Depression and in Japan recently. One argument that some economists make is that when the interest rate hits a floor of zero, monetary policy becomes ineffective. ${ }^{16}$ This argument is a fallacy for the reasons outlined in Meltzer (1995) and Mishkin (1996b). Monetary policy works through many other asset prices besides those of short-term debt securities, and so even when short-term interest rates hit the floor of zero, monetary policy can still be effective, and indeed was so during the Great Depression (see Romer 1992).

Nonetheless, monetary policy becomes more difficult during deflationary episodes when interest rates hit a floor of zero because the usual guides to the conduct of monetary policy are no longer relevant. In recent years, much of the research on how central banks should optimally conduct monetary policy focus on so-called Taylor rules, in which the central

\footnotetext{
${ }^{15}$ Technically this debt-deflation mechanism requires that the deflation be unanticipated: i.e., it is a surprise after the debt contracts have been written. Because in industrial countries many of these contracts are so long, even a deflation that becomes anticipated after a period of time, still is unanticipated from the point of view of many debt contracts and the debt deflation story still holds. Clearly, if debt contracts are of very short duration, as is typically the case in emerging market countries, then deflations, even when they occur, are less likely to be unanticipated and so the debt deflation mechanism is inoperative (see Mishkin 1997).

${ }^{16}$ Summers (1991) is one prominent example, and recently officials of the Bank of Japan have used this argument to indicate that expansionary monetary policy is likely to be ineffective in promoting Japanese recovery.
} 
bank sets the short-term interest rates at a level which depends on both output and inflation gaps. The Taylor (1999) volume is an excellent example of this type of research. However, once the interest rate hits a floor of zero, all of the research on optimal monetary policy rules represented by work of the type in the Taylor (1999) volume is no longer useful because manipulating short-term interest rates is no longer an effective tool of monetary policy. In such a deflationary environment, central banks do have the ability to lift the economy out of recession by pursuing expansionary policy and creating more liquidity, but it becomes much less clear how far they need to go. This rightfully makes central bankers quite uncomfortable. Therefore, an important disadvantage of too low a level of the long-run inflation target is therefore that it makes it more likely that deflationary environments will occur in which central bankers will be more at sea without the usual knowledge to guide them, making it harder for them to get monetary policy exactly right.

Another reason why central banks might be better off with a long-run inflation goal above zero, is that it is crucial that they not be perceived as being overly obsessed with controlling inflation at the expense of output stability. If a central bank is perceived as an "inflation nutter" in Mervyn King's (1996) terminology, in which the central bank puts no weight on output fluctuations in making its decisions about monetary policy, it is likely to lose the support of the public. Too low an inflation target, say 0 or even $1 \%$, may signal to the public that the central bank does not care sufficiently about the public's concerns.

On the other hand, Fischer (1986), Feldstein (1997) and the papers in Feldstein (1999) find that lowering the inflation rate to zero in industrial countries from currently low levels reduces distortions caused by the interaction of inflation with the tax system, and this can produce substantial welfare gains, on the order of $1 \%$ of GDP. ${ }^{17}$ However, these distortions can also be eliminated by changes in the tax code and so it is not clear that they provide a justification for choosing a zero long-run inflation goal.

Emerging market countries that grow at high levels may be better off having inflation rates slightly higher than those in industrialized countries. High growth countries typically experience real exchange rate appreciation by an amount proportional to the relative difference

\footnotetext{
${ }^{17}$ Welfare costs arising from inflation because interest is not paid on high-powered money (the so-called "shoe leather" costs) are estimated to be an order of magnitude smaller than costs due to tax distortions and are thus unlikely to be important for deciding the optimal long-run inflation goal. For recent papers, see Lucas (1981), Fischer (1986), Cooley and Hansen (1989), and Lucas (2000).
} 
of traded to non-traded sector productivity growth relative to the rest of the world (the HarrodBelassa-Samuelson effect). If it is appropriate for these countries to aim at traded goods inflation similar to industrialized countries in the long run, then trend real appreciation requires a domestic non-traded goods inflation that is somewhat higher. Hence the long-run inflation goal in high growth economies might need to be slightly higher than it would be desirable for average-growth countries. This provides an explanation for why in Chile, a highgrowth country, the long-term inflation target range has been chosen at 2-4\% per year.

In sum, given the conflicting arguments above, what is an appropriate long-run goal for inflation is still an open question. As a practical matter, all inflation targeting countries have chosen long-run inflation goals slightly above zero, with the midpoints of the long-run target ranges lying between 1 and 3\% (see Table 1). Future research may help central banks to decide on whether a long-run goal outside this range is appropriate and provide more precision as to what this goal should be.

\subsection{Price Level Versus Inflation Target}

Currently, all countries who have adopted inflation targeting have chosen to target inflation rather than the price level. However, which of these two targets would result in better economic performance is also an open question.

There are two key advantages of a price-level target relative to an inflation target. The first is that a price-level target can reduce the uncertainty about where the price level will be over long horizons. With an inflation target, misses of the inflation target are not reversed by the central bank. The result is that inflation will be a stationary stochastic process, that is, integrated of order zero, I(0), while the price level will be nonstationary, an I(1) process. The result is that the uncertainty of where the price level will be in the future grows with the forecast horizon. This uncertainty can make long-run planning difficult and may therefore lead to a decrease in economic efficiency. Although McCallum (1999) has argued that the amount of long-run uncertainty about the future price level that would arise from successful adherence to an inflation target may not be all that large, it still complicates the planning process and may lead to more mistakes in investment decisions.

The second possible advantage of a price-level target is that in models with a high degree of forward-looking behavior on the part of economic agents (e.g., Svensson 1999, 
Woodford 1999, Svensson and Woodford 1999, Clarida, Gali, and Gertler 1999, Ditmar, Gavin, and Kydland 1999, 2000, and Vestin 2000) it produces less output variance than an inflation target. However, empirical evidence (e.g., Fuhrer 1997) does not clearly support forward-looking expectations formation, and models with forward-looking behavior have counterintuitive properties that seem to be inconsistent with inflation dynamics (Estrella and Fuhrer 1998).

The traditional view, forcefully articulated by Fischer (1994), argues that a price-level target produces more output variability than an inflation target because unanticipated shocks to the price level are not treated as bygones and must be offset. ${ }^{18}$ A price-level target requires that overshoots or undershoots of the target must be reversed and this could impart significantly more volatility to monetary policy and, with sticky prices, to the real economy in the short run.

Although the models with forward-looking price setting cited above do not find that this feature of a price-level target increases output variability, they do not focus on one particular problem with a price-level target: the fact that a price-level target may lead to more frequent episodes of deflation. As we have seen in the previous subsection, episodes of deflation present policymakers with two problems: a possible increase in financial instability with potential high output losses for the economy and an increased likelihood that nominal interest rates hit a floor of zero, making the conduct of monetary policy more complicated.

Another problem for a price-level target that has received little attention in the literature is the presence of measurement error in inflation. Most research on measurement error takes the view that it is inflation that is measured with error rather than the price level and this was the approach taken by the Boskin Commission. ${ }^{19}$ This implies that the measurement error in the price level is I(1), so that a price-level target results in growing uncertainty about the true price level as the forecast horizon grows. Thus many of the arguments that a price-level target results in lower long-run uncertainty about the true price level may be overstated.

\footnotetext{
${ }^{18}$ This view is supported by simulations of macroeconometric models with backward-looking expectations which typically find that a price-level target leads to greater variability of output and inflation than an inflation target. E.g., see Haldane and Salmon (1995).

${ }^{19}$ See Boskin et al. (1996), Moulton (1996), and Shapirio and Wilcox (1996), for example.
} 
The conflicting arguments above indicate that whether price level rather than inflation targets would produce better outcomes is an open question. Given this uncertainty about the benefits of price level targeting, it is not surprising that no central bank has decided to target the price level in recent years. However, the arguments made here for preferring an inflation target over a price-level target, do not rule out hybrid policies, which combine features of an inflation and a price-level target and so might provide the best of both worlds.

An inflation target could be announced with a commitment to some error correction in which target misses will be offset to some extent in the future. Recent research shows that an inflation target with a small amount of error correction can substantially reduce the uncertainty about the price level in the long run, but still generate very few episodes of deflation (e.g., Black, Macklem, and Rose 1997, King 1999, and Battini and Yates 1999). Furthermore, by putting a small weight on the price level error correction term, the trade-off between output and inflation fluctuations can be improved (e.g., see also Williams 1999, Smets 2000, Gaspar and Smets 2000, McLean and Pioro 2000). Evaluating hybrid policies of this type is likely to be a major focus of future research.

One issue that would have to be addressed if such a hybrid policy was adopted is how it could be explained to the public. As is emphasized in Bernanke and Mishkin (1997), Mishkin (1999b), and Bernanke et al. (1999), critical to the success of inflation targeting is that it provides a vehicle for more effective communication with the public. The public will clearly not understand the technical jargon of error correction models. However, an error correction feature of an inflation targeting regime could be fairly easily communicated by not only announcing an intermediate-term inflation target, but also by indicating that there is a target for the average inflation rate over a longer period, say five years.

Another hybrid policy is to pursue an inflation target under normal conditions, but provide for an escape clause which puts in place a price level target only when the unusual condition of deflation sets in, particularly if interest rates near a floor of zero. The inflation target under normal conditions would not require that overshoots of the inflation target be reversed and so would not make episodes of deflation more likely. On the other hand, when deflation sets in, then putting in place a price level target to induce expectations of reflation of the economy would not only make it less likely that nominal interest rates would hit a floor of zero, but also would lead to higher inflation expectations which would lower real interest 
rates, thereby stimulating the economy, and would help induce a rise in the price level that would repair balance sheets. Given the success of a price level target in ameliorating the effects of the Great Depression in Sweden in the 1930s (Berg and Jonung 1998), price level targets have recently been proposed to help jump start the Japanese economy (e.g., Bernanke 1999, Blinder 1999, Goodfriend 1999, and Svensson 2000).

\section{Conclusions}

The emergence of inflation targeting over the last ten years has been an exciting development in the approach of central banks to the conduct of monetary policy. The review in this paper has indicated that inflation targeting has been quite successful in controlling inflation and improving the performance of the economy. However, as our discussion of operational design issues for inflation targeting and unresolved issues, there is still much to learn about how to best operate inflation targeting regimes. We expect that future experience and research will help us to refine the inflation targeting approach, hopefully improving the process of monetary policymaking further.

\section{References}

Anderson, P. and D. Gruen, 1995. "Macroeconomic Policies and Growth," in Palle Anderson, Jacqui Dwyer and David Gruen (eds.): Productivity and Growth (Reserve Bank of Australia: Sydney): 279-319.

Andres, J. and I. Hernando, 1999. "Does Inflation Harm Economic Growth? Evidence from the OECD," in Martin Feldstein (ed.): The Costs and Benefits of Price Stability, University of Chicago Press: Chicago.

Akerlof, G., Dickens, W., and G. Perry, 1996. "The Macroeconomics of Low Inflation," Brookings Papers on Economic Activity 1: 1-59.

Almeida, A. and C. Goodhart, 1998. "Does the Adoption of Inflation Targets Affect Central Bank Behaviour?”. Banca-Nazionale-del-Lavoro-Quarterly-Review 51(204), Supplement March: pp. 19-107.

Ball, L., 1999. "Policy Rules For Open Economies”, in John Taylor (ed.): Monetary Policy Rules. The University of Chicago Press: Chicago. IL.

Banco de Mexico, 2000. Inflation Report, July-September 2000 (Banco de Mexico: Mexico City).

Bank of Brazil, 1999. Inflation Report, July 1999 (Bank of Brazil: Brasilia).

Battini, N. and A. Haldane, 1999. "Forward-Looking Rules for Monetary Policy", in John Taylor Monetary Policy Rules. The University of Chicago Press: Chicago, IL.

Battini, N. and T. Yates, 1999. "Hybrid Inflation and Price Level Targeting," mimeo., Bank of England. 
Barro, R., 1995. "Inflation and Economic Growth," National Bureau of Economic Research Working Paper No. 5326.

Berg, C. and L. Jonung, 1998. "Pioneering Price Level Targeting: the Swedish Experience, 1931-37," Sveriges Riksbank Working Paper Series 63, June.

Bernanke, B. 1999, "Japanese Monetary Policy: A Case of Self Induced Paralysis," mimeo, Princeton University.

Bernanke, B. S., Laubach, T., Mishkin, F. S. and A. S. Posen, 1999. Inflation Targeting: Lessons from the International Experience, Princeton University Press: Princeton.

Bernanke, B. and M. Gertler, 1999. "Monetary Policy and Asset Price Volatility". In New Challenges for Monetary Policy. Federal Reserve Bank of Kansas City: Kansas City.

Bernanke, B. S. and F. S. Mishkin, 1997. "Inflation Targeting: A New Framework for Monetary Policy?" Journal of Economic Perspectives 11, 2: 97-116.

Black, R., Macklem and D. Rose, 1997. "On Policy Rules for Price Stability," Price Stability, Inflation Targets and Monetary Policy, Proceedings of a Conference held by Bank of Canada, Ottawa, Canada: 411-61.

Blinder, A., 1999. "Monetary Policy at the Zero Lower Bound: Balancing the Risks," presented at the Federal Reserve Bank of Boston Conference, Monetary Policy in a Low Inflation Environment," October 18-20, 1999.

Brash, D.. 2000. "Inflation Targeting in New Zealand, 1988-2000," Speech to the Trans-Tasman Business Cycle, Melbourne, February 9.

Bruno, M. and W. Easterly, 1996. "Inflation and Growth: In Search of a Stable Relationship," Federal Reserve Bank of St. Louis Review, 78 (3): 139-46

Boskin, M. J., Dulberger, Ellen R., Gordon, R. J., Griliches, Z. and D. W. Jorgenson, 1996. "Toward a More Accurate Measure of the Cost of Living," Final Report to the Senate Finance Committee, December.

Carruth, A. and A. Oswald, 1989. Pay Determination and Industrial Prosperity, Oxford University Press, Clarendon Press, Oxford.

Carstens, A. and A. Werner, 1999. "Mexico's Monetary Policy Framework Under a Floating Exchange Rate Regime," Banco de Mexico Research Paper 9905, May.

Cecchetti, S. and M. Ehrmann, 2000. "Does Inflation Targeting Increase Output Volatility? An International Comparison of Policimakers preferences and Outcomes". Central Bank of Chile Working Papers 69, April. http://www.bcentral.cl/Estudios/DTBC/69/dtbc69.pdf

Cecchetti, S., H. Genberg, J. Lipski, and S. Wadhwani, 2000. "Asset Prices and Central Bank Policy”. Geneva Reports on the World Economy, No.., International Center for Monetary and Banking Studies and Centre for Economic Policy Research, July.

Central Bank of Chile, 2000'. Monetary Policy Report, May.

Central Bank of Chile, 2000b. Monetary Policy of the Central Bank of Chile: Objectives and Transmission, May.

Clarida, R, J. Gali, and M. Gertler, 1999. "The Science of Monetary Policy: A New Keynesian Perspective," Journal of Economic Literature, 37 (December): 1661-1707. 
Cooley, T. F. and G. D. Hansen, 1989. "The Inflation Tax in a Real Business Cycle Model," American Economic Review, 79: 733-748.

Corbo, V., O. Landerretche, and K. Schmidt-Hebbel, 2001. "Does Inflation Targeting Make a Difference", in N. Loayza and R. Soto (eds.): Ten Years of Inflation Targeting: Design, Performance, Challenges, Central Bank of Chile: Santiago, Chile, forthcoming.

Corbo, V. and K. Schmidt-Hebbel, 2000. "Inflation Targeting in Latin America". Paper presented at the Latin American Conference on Financial and Fiscla Polciies, Stanford University, November.

Cozier, B. and J. Selody, 1992. "Inflation and Macroeconomic Performance: Some Cross-Country Evidence," Bank of Canada Working Paper No. 92-06.

Debelle, G. and S. Fischer, 1994. "How Independient Should a Central Bank Be?". In Goals, Guidelines, and Constraints Facing Monetary Policymakers: Proceedings of a Conference held at North Falmouth. Boston: Federal Reserve Bank of Boston.

Ditmar, R., Gavin, W.T., and F. E. Kydland, 1999. "The Inflation-Output Variability Tradeoff and Price Level Targets," Review, Federal Reserve Bank of St. Louis: 23-31.

Ditmar, R., Gavin, W.T., and F. E. Kydland, 2000. "What Do New-Keynesian Phillips Curves Imply for PriceLevel Targeting," Review, Federal Reserve Bank of St. Louis: 21-30.

Drew, A and A. Orr, 1999. "The Reserve Bank's Role in the Recent Business Cycle: Actions and Evolution," Reserve Bank of New Zealand Bulletin, 62, No. 1.

Estrella, A., and J. Fuhrer, 1998. "Dynamic Inconsistencies: Counterfactual Implications of a Class of Rational Expectations Model," Federal Reserve Bank of Boston Working Paper No. 98-5, July, forthcoming in American Economic Review.

Estrella, A. and Mishkin, F. S., 1999. "Rethinking the Role of NAIRU in Monetary Policy: Implications of Model Formulation and Uncertainty", in John Taylor (ed.): Monetary Policy Rules. The University of Chicago Press: Chicago, IL.

Feldstein, M., 1997. "Capital Income Taxes and the Benefits of Price Stability," NBER Working Paper No. 6200, September.

Feldstein, M., 1999. The Costs and Benefits of Price Stability. NBER Conference Report series. Chicago and London: University of Chicago Press.

Fisher, I., 1933. "The Debt-Deflation Theory of Great Depressions", Econometrica, 1: 337-57.

Fischer, S., 1986. Indexing, Inflation and Economic Policy, MIT Press, Cambridge, Mass.

Fischer, S. 1993. "The Role of Macroeconomic Factors in Growth," Journal of Monetary Economics, 32 (3): 485512.

Fischer, S.. 1994. "Modern Central Banking," in Forest Capie, Charles Goodhart, Stanley Fischer and Norbert Schnadt, The Future of Central Banking, Cambridge University Press, Cambridge, U.K.: 262-308.

Fuhrer, J., 1997. "The (Un)Importance of Forward-Looking Behavior in Price Specifications," Journal of Money, Credit and Banking, 29 (3): 338-50.

Gaspar, V. and F. Smets, 2000. "Price Level Stability: Some Issues," mimeo, European Central Bank. 
Goodfriend, M., 1999. "Overcoming the Zero Bound on Interest Rate Policy," presented at the Federal Reserve Bank of Boston Conference, Monetary Policy in a Low Inflation Environment," October 18-20, 1999.

Grier, K. and G. Tullock, 1989. "An Empirical Analysis of Cross-National Economic Growth, 1951-80”. Journal of Monetary Economics 24 (2), September: pp. 259-76.

Groshen, E.L. and Schweitzer, M.E., 1996. "The Effects of Inflation on Wage Adjustments in Firm-Level Data: Grease or Sand?" Federal Reserve Bank of New York Staff Reports, No. 9.

Groshen, E.L. and Schweitzer, M.E., 1999. "Identifying Inflation's Grease and Sand Effects in the Labor Market," in Martin Feldstein, ed., The Costs and Benefits of Price Stability University of Chicago Press, Chicago: 273-308.

Haldane, A. G. and C.K. Salmon,1995. "Three Issues in Inflation Targets," in Andrew G. Haldane (ed.): Targeting Inflation, Bank of England, London: 170-201.

IMF, 2000. International Financial Statistics, IMF, Washington D.C., USA.

Ingrams, P. 1991. "Ten Years of Manufacturing Wage Settlements," Oxford Review of Economic Policy, Spring.

King, M., 1996. "How Should Central Banks Reduce Inflation?- Conceptual Issues," in Achieving Price Stability, Federal Reserve Bank of Kansas City, Kansas City, MO: 53-91.

King, M., 1999, "Challenges for Monetary Policy: New and Old," in New Challenges for Monetary Policy, Federal Reserve Bank of Kansas City, Kansas City, Missouri:11-57.

Kormendi, R.C. and P.G. Meguire, 1985. "Macroeconomic Determinants of Growth: Cross-Country Evidence," Journal of Monetary Economics, 16 (2): 141-63.

Lucas, R.E., 1981. "Discussion of Stanley Fischer, 'Towards an Understanding of the Costs of Inflation: II,"' Carnegie-Rochester Conference Series on Public Policy, Autumn, 43-52.

Lucas, R.E., 2000. "Inflation and Welfare," Econometrica, 68 (2): 247-74.

MacFarlane, I. J. 1999. "Statement to Parliamentary Committee," in Reserve Bank of Australia Bulletin, January: 16-20.

Mahadeva, L. and G. Sterne, eds., 2000. Monetary Policy Frameworks in a Global Context London: Bank of England CCBS and Routeledge.

Masson, P., M. Savastano, and S.F. Sharma, 1997. "The Scope for Inflation Targeting in Developing Countries," IMF Working Paper 97/130, October.

McCallum, B. T, 1999. "Issues in the Design of Monetary Policy Rules," in John B. Taylor and Michael Woodford (eds): Handbook of Macroeconomics, North Holland, Amsterdam.

McCallum, B.T. and E. Nelson, 1999. "Performance of Operational Policy Rules in an Estimated Semi-Classical Structural Model", in John Taylor (ed.): Monetary Policy Rules. The University of Chicago Press: Chicago. IL.

McLaughlin, K., 1994. “Rigid Wages?”. Journal of Monetary Economics 34(3), December: pp. 383-414.

McLean, D. and H. Pioro, 2000. "Price Level Targeting -- The Role of Credibility," paper presented at the Bank of Canada Conference, Price Stability and the Long-Run Target for Monetary Policy, June 8-9, 2000.

Meltzer, A.H., 1995. "Monetary, Credit and Other Transmission Mechanism Processes: A Monetarist Perspective," Journal of Economic Perspectives, 9: 49-72. 
Mishkin, F.S., 1991. "Asymmetric Information and Financial Crises: A Historical Perspective," in R. Glenn Hubbard (ed.): Financial Markets and Financial Crises, University of Chicago Press: Chicago: 69-108.

Mishkin, F.S.., 1996a. "Understanding Financial Crises: A Developing Country Perspective," in Michael Bruno and Boris Pleskovic, eds., Annual World Bank Conference on Development Economics, World Bank, Washington D.C.: $29-62$.

Mishkin, F.S., 1996b. "The Channels of Monetary Transmission: Lessons for Monetary Policy," Banque De France Bulletin Digest No. 27: 33-44.

Mishkin, F.S., 1997. "The Causes and Propagation of Financial Instability: Lessons for Policymakers," Maintaining Financial Stability in a Global Economy, Federal Reserve Bank of Kansas City, Kansas City, MO.: 55-96.

Mishkin, F.S., 1998. "Promoting Japanese Recovery," in Kenichi Ishigaki and Hiroyuki Hino, eds., Towards the Restoration of Sound Banking Systems in Japan -- the Global Implications (Kobe University Press and International Monetary Fund: Kobe 1998). 130-161.

Mishkin, F.S., 1999a. "Lessons from the Asian Crisis," Journal of International Money and Finance, 18, 4: 709723.

Mishkin, F.S., 1999b. "International Experiences with Different Monetary Policy Regimes," Journal of Monetary Economics, Vol. 43, \#3: 579-606.

Mishkin, F.S., 2000a. "Issues in Inflation Targeting," mimeo., paper presented at the Bank of Canada Conference, Price Stability and the Long-Run Target for Monetary Policy, June 8-9, 2000.

Mishkin, F.S. 2000b. "Inflation Targeting in Emerging Market Countries," American Economic Review, May, 90, \#2: .

Mishkin, F.S., 2000c. "From Monetary Targeting to Inflation Targeting: Lessons From Industrialized Countries," paper presented at Banco de Mexico Conference, "Stabilization and Monetary Policy: The International Experience," Mexico City, November 14-15, 2000.

Mishkin, F. S. and M. Savastano, 2000. "Monetary Policy Strategies for Latin America," NBER Working Paper No. 7617, forthcoming in the Journal of Development Economics.

Morandé, F. 2001. "A Decade of Inflation Targeting in Chile: Developments, Lessons, Challenges”, in N. Loayza and R. Soto (eds.): Ten Years of Inflation Targeting: Design, Performance, Challenges, Central Bank of Chile: Santiago, Chile, forthcoming.

Morandé, F. and K. Schmidt-Hebbel, 1997. "Inflation Targets and Indexation in Chile", mimeo, Central Bank of Chile, August.

Morandé, Felipe and K. Schmidt-Hebbel, 2000. "Inflation Targets and Indexation in Chile", mimeo, Central Bank of Chile, August.

Moulton, B.R., 1996. "Bias in the Consumer Price Index: What is the Evidence," Journal of Economic Perspectives 10 (4): 159-77.

Poole, W., 1999. "Is Inflation Too Low," Review, Federal Reserve Bank of St. Louis, 81, 4: 3-10.

Romer, C., 1992. "What Ended the Great Depression?" Journal of Economic History, December 1992, 52, \#4, 757-784. 
Schaechter, A., M.R. Stone, and M. Zelmer, 2000. "Practical Issues in the Adoption of Inflation Targeting by Emerging Market Countries", mimeo, IMF.

Shapiro, M. D. and D.W. Wilcox, 1996. "Mismeasurement in the Consumer Price Index, An Evaluation," in Ben S. Bernanke and Julio J. Rotemberg, eds. NBER Macroeconomics Annual, MIT Press, Cambridge, Mass.: 83154.

Sherwin, M., 1999. "Inflation Targeting: 10 Years On," Speech to New Zealand Association of Economists Conference, Rotorua, New Zealand, July 1.

Smets, F., 2000. "What Horizon for Price Stability," European Central Bank Working Paper 24.

Sterne, G., 2000. "The Use of Inflation Targets in a Global Context”. Mimeo, Bank of England.

Stevens, G. R., 1999. "Six Years of Inflation Targeting," Reserve Bank of Australia Bulletin, May: 46-61.

Stevens, G. and G. Debelle, 1995. "Monetary Policy Goals for Inflation in Australia," in Andrew G. Haldane, ed., Targeting Inflation, Bank of England, London: 170-201.

Summers, L.H., 1991. "How Should Long-Term Monetary Policy Be Determined?" Journal of Money Credit and Banking, 23: 625-631.

Svensson, L.E.O., 1997. "Inflation Forecast Targeting: Implementing and Monitoring Inflation Targets," European Economic Review, 41: 1111-1146.

Svensson, L. E.O, 1999. "Price-Level Targeting Versus Inflation Targeting: A Free Lunch," Journal of Money, Credit and Banking, 31: 277-95.

Svensson, L. E.O., 2000. "The Zero Bound in an Open Economy: A Foolproof Way of Escaping From a Liquidity Trap," presented at the Bank of Japan's Ninth International Conference, The Role of Monetary Policy Under Low Inflation: Deflationary Shocks and Their Policy Response, July 3-4, 2000.

Svensson, L. E.O., and M. Woodford, 1999. "Implementing Optimal Monetary Policy Through Inflation Forecast Targeting," Stockholm University, IIES, mimeo.

Taylor, J. (ed.) 1999. Monetary Policy Rules, University of Chicago Press for the NBER, Chicago.

Taylor, J., 2000. "Using Monetary Policy Rules in Emerging Market Economies”. Mimeo, Stanford University, November.

Vestin, D., 2000. "Price Level Targeting Versus Inflation Targeting in a Forward Looking Model." mimeo., Stockholm University.

Williams, J.C., 1999. "Simple Rules for Monetary Policy," Finance and Economics Discussion Series, Board of Governors of the Federal Reserve System.

Woodford, M., 1999. "Inflation Stabilization and Welfare," mimeo., Princeton University.

Yates, A. 1995. "On the Design of Inflation Targets," in A.G. Haldane, ed., Targeting Inflation, Bank of England, London. 


\section{Data Appendix}

Definitions and sources of the data used in section 2 are the following.

IT: dummy variable for having in place inflation targeting. Specifies a value of 1 ( 0 otherwise) for a year for which at least 6 months are covered by a previously announced inflation target.

Source: country sources and Schaechter et al. (2000).

Inf: CPI inflation, normalized as percentage variation of the annual average CPI divided by one plus the percentage variation of the annual average CPI.

Source: IMF: "International Financial Statistics", various issues, code 64e.

MT: dummy variable for having in place monetary growth targets. Specifies a value of 1 (0 otherwise) for a year for which any month is covered by a previously announced monetary target.

Source: country sources and JP Morgan: "Guide to Central Bank Watching".

BW: exchange-rate band width, normalized as the band width divided by one plus the band width.

Source: IMF: "Exchange Arrangements and Exchange Restrictions", various issues.

Fiscal: the ratio of the government surplus to GDP.

Source: country sources and IMF: "International Financial Statistics", various issues, codes 80 and 99 b.

Fin: financial depth measured as the ratio of M2 to GDP.

Source: country sources and IMF: "International Financial Statistics", various issues, codes 80 and 99b.

Open: trade openness measured as the ratio of the sum of exports and imports to GDP.

Source: country sources and IMF: "International Financial Statistics", codes 90c, 98c, and 99b.

CBFI: dummy for central-bank formal independence. Specifies a value of 1 ( 0 otherwise) for a year for which any month is covered by central-bank formal independence. Formal independence is attained when a central bank is established as a legally independent and/or autonomous state institution.

Source: country sources and JP Morgan: "Guide to Central Bank Watching”.

CBGI: dummy for central-bank goal independence. Specifies a value of 1 ( 0 otherwise) for a year for which any month is covered by central-bank goal independence. Goal independence is attained when the Central Bank alone determines the levels for its monetary policy targets (i.e., exchange rate, monetary growth, and/or inflation targets). When target levels are determined separately by the government or congress, jointly by the bank and either government or congress, or when a government representative casts votes on central bank board decisions, the central bank is considered goal-dependent.

Source: country sources and JP Morgan "Guide to Central Bank Watching”.

CBII: dummy for central-bank instrument independence. Specifies a value of 1 ( 0 otherwise) for a year for which any month is covered by central-bank instrument independence. Instrument independence is attained when the central bank sets freely its instrument in its pursuit of monetary policy goals. When central bank policy decisions are either subject to government approval or can be reversed by the government, instrument independence is not in place.

Source: country sources, JP Morgan: "Guide to Central Bank Watching”, and Schaechter et al. (2000). 


\section{Figure 1}

\section{Inflation at Adoption of Inflation Targeting in 19 Countries: 1988-2000}

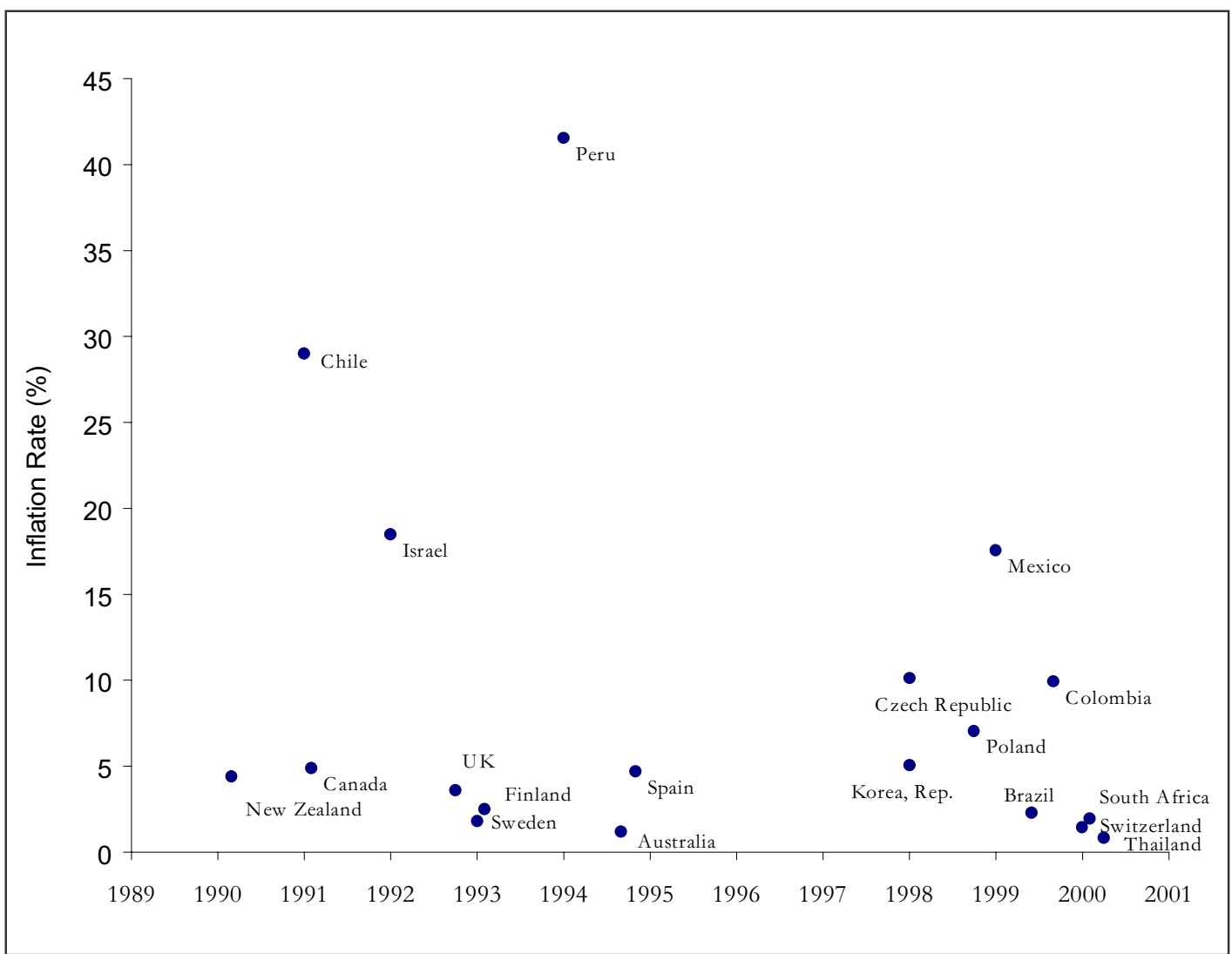

Note: Annual inflation rates are those observed one quarter before adopting IT.

Source: Authors' calculations based on data from IFS, country sources, and Schaechter et al. (2000).

\section{Table 1}

\section{Country Samples of Inflation Targeters and Non-Targeters}

\begin{tabular}{lll} 
Inflation Targeters & & Non-Targeters \\
\hline Australia & United Kingdom & Denmark \\
Brazil & Mexico & France \\
Canada & New Zealand & Germany \\
Chile & Peru & Italy \\
Colombia & Poland & Japan \\
Czech Republic & South Africa & Norway \\
Finland & Spain & Portugal \\
Israel & Sweden & United States \\
Korea & Thailand & Switzerland \\
\hline
\end{tabular}


Table 2

\section{Implementation and Design of Inflation Targeting in 19 Countries}

\begin{tabular}{|c|c|c|c|c|c|c|c|c|}
\hline Country & $\begin{array}{l}\text { Date } \\
\text { Introduced }\end{array}$ & $\begin{array}{l}\text { Target Price } \\
\text { Index }\end{array}$ & Target Width & Target Horizon & Escape Clauses & $\begin{array}{l}\text { Accountability of } \\
\text { Target Misses }\end{array}$ & Target set by & $\begin{array}{l}\text { Publications and } \\
\text { Accountability }\end{array}$ \\
\hline Australia & Sep. 1994 & Core CPI & $2-3 \%$ & $\begin{array}{l}\text { Over one business } \\
\text { cycle }\end{array}$ & None & None & $\begin{array}{l}\text { Jointly by } \\
\text { Gov and CB }\end{array}$ & $\begin{array}{l}\text { Pub. of inflation report. } \\
\text { Pub. of inflation projections (2- } \\
\text { year point estimate) }\end{array}$ \\
\hline Brazil & Jun. 1999 & Headline CPI & $\begin{array}{l}\text { 1999: } 8 \%( \pm 2 \%) \\
\text { 2000: } 6 \%( \pm 2 \%) \\
2001: 4 \%( \pm 2 \%)\end{array}$ & 1 year & None & $\begin{array}{l}\text { Issuance of open } \\
\text { letter to Minister of } \\
\text { Finance explaining } \\
\text { target breach and } \\
\text { measures taken (and } \\
\text { the time required) to } \\
\text { bring inflation within } \\
\text { the target }\end{array}$ & $\begin{array}{l}\text { Gov in } \\
\text { consultation } \\
\text { with CB }\end{array}$ & $\begin{array}{l}\text { Pub. of inflation report. } \\
\text { Pub. of inflation projections ( } 2- \\
\text { year fan chart). } \\
\text { Pub of extract of Board meetings. } \\
\text { Pub. of models used for inflation } \\
\text { outlook }\end{array}$ \\
\hline Canada & Feb. 1991 & $\begin{array}{l}\text { Core CPI } \\
\text { (excl. food, } \\
\text { energy, and } \\
\text { indirect taxes) }\end{array}$ & $\begin{array}{l}\text { 1991: } 3-5 \% \\
\text { 1992: } 2-4 \% \\
\text { Jun. } 94: 1.5-3.5 \% \\
\text { 1995-2001: } 1-3 \%\end{array}$ & $\begin{array}{l}\text { 1991: } 22 \text { months } \\
\text { Since 1992: multi- } \\
\text { year }\end{array}$ & $\begin{array}{l}\text { Revision of target } \\
\text { path under } \\
\text { exceptional } \\
\text { circumstances } \\
\text { (ex. major oil } \\
\text { price shock, } \\
\text { natural disaster) }\end{array}$ & Public explanation & $\begin{array}{l}\text { Jointly by } \\
\text { Gov and CB }\end{array}$ & $\begin{array}{l}\text { Pub. of monetary policy report. } \\
\text { Pub. of inflation projections (1- } \\
\text { year point estimate) }\end{array}$ \\
\hline Chile & Jan. 1991 & Headline CPI & $\begin{array}{l}\text { 1991: } 15-20 \% \\
\text { 1992: } 13-16 \% \\
\text { 1993: } 10-12 \% \\
\text { 1994: } 9-11 \% \\
\text { 1995: } \pm 8 \% \\
\text { 1996: } \pm 6.5 \% \\
\text { 1997: } \pm 5.5 \% \\
\text { 1998: } \pm 4.5 \% \\
\text { 1999: } \pm 4.3 \% \\
\text { 2000: } \pm 3.5 \% \\
\text { 2001 onwards: } 2- \\
4 \%\end{array}$ & $\begin{array}{l}\text { 1991-2000: } 1 \text { year } \\
\text { 2001 onwards: } \\
\text { indefinite }\end{array}$ & None & None & $\begin{array}{l}\text { CB in } \\
\text { consultation } \\
\text { with Gov }\end{array}$ & $\begin{array}{l}\text { Pub. of inflation report ( } 2000) \text {. } \\
\text { Pub. of minutes of monetary } \\
\text { policy meetings. } \\
\text { Pub. of inflation projections (2- } \\
\text { year fan chart) }\end{array}$ \\
\hline Colombia & Sep. 1999 & Headline CPI & $\begin{array}{l}\text { 1999: } 15 \% \\
2000: 10 \% \\
2001: 8 \% \\
2002: 6 \%\end{array}$ & 1 year & None & None & $\begin{array}{l}\text { Jointly by } \\
\text { Gov and CB }\end{array}$ & Pub. of inflation report \\
\hline
\end{tabular}




\section{Implementation and Design of Inflation Targeting in 19 Countries}

\begin{tabular}{|c|c|c|c|c|c|c|c|c|}
\hline Country & $\begin{array}{l}\text { Date } \\
\text { Introduced }\end{array}$ & $\begin{array}{l}\text { Target Price } \\
\text { Index }\end{array}$ & Target Width & Target Horizon & Escape Clauses & $\begin{array}{l}\text { Accountability of } \\
\text { Target Misses }\end{array}$ & Target set by & $\begin{array}{l}\text { Publications and } \\
\text { Accountability }\end{array}$ \\
\hline $\begin{array}{l}\text { Czech } \\
\text { Republic }\end{array}$ & Jan. 1998 & $\begin{array}{l}\text { Core CPI } \\
\text { (excl. } \\
\text { regulated } \\
\text { prices and } \\
\text { indirect taxes) }\end{array}$ & $\begin{array}{l}\text { 1998: } 5.5-6.5 \% \\
1999: 4-5 \% \\
2000: 3.5-5.5 \% \\
2001: 2-4 \%\end{array}$ & 1 year & $\begin{array}{l}\text { Natural disasters, } \\
\text { global raw } \\
\text { material price } \\
\text { shocks, exchange } \\
\text { rate shocks } \\
\text { unrelated to } \\
\text { domestic } \\
\text { economic } \\
\text { fundamentals and } \\
\text { monetary policy, } \\
\text { and agricultural } \\
\text { production shocks }\end{array}$ & None & $\mathrm{CB}$ & $\begin{array}{l}\text { Pub. of inflation report (1998). } \\
\text { Pub. of minutes of monetary } \\
\text { policy meetings. } \\
\text { Pub. of inflation projections (1- } \\
\text { year range) }\end{array}$ \\
\hline Finland & $\begin{array}{l}\text { Feb. } 1993 \\
\text { to Jun. } \\
1998\end{array}$ & $\begin{array}{l}\text { Core CPI } \\
\text { (excl. indirect } \\
\text { taxes, } \\
\text { subsidies, } \\
\text { housing } \\
\text { prices, and } \\
\text { mortgage } \\
\text { interest) }\end{array}$ & $\begin{array}{l}\text { Annual average of } \\
2 \% \text { by } 1995\end{array}$ & $\begin{array}{l}\text { Until 1995: multi- } \\
\text { year } \\
\text { Since 1996: indefinite }\end{array}$ & None & None & $\mathrm{CB}$ & None \\
\hline Israel & Jan. 1992 & Headline CPI & $\begin{array}{l}\text { 1992: } 14-15 \% \\
\text { 1993: } 10 \% \\
\text { 1994: } 8 \% \\
\text { 1995: } 8-11 \% \\
\text { 1996: } 8-10 \% \\
\text { 1997: } 7-10 \% \\
\text { 1998: } 7-10 \% \\
\text { 1999: } 4 \% \\
\text { 2000: } 3-4 \% \\
2001: 3-4 \%\end{array}$ & 1 year & None & $\begin{array}{l}\text { Public explanation of } \\
\text { deviation of inflation } \\
\text { forecast from target in } \\
\text { excess of } 1 \%\end{array}$ & $\begin{array}{l}\text { Gov in } \\
\text { consultation } \\
\text { with CB }\end{array}$ & Pub. of inflation report (1998) \\
\hline Korea, Rep. & Jan. 1998 & & $\begin{array}{l}\text { 1998: } 9 \%( \pm 1 \%) \\
\text { 1999: } 3 \%( \pm 1 \%) \\
\text { 2000: } 2.5 \%( \pm 1 \%) \\
2001 \text { onwards: } \\
2.5 \%\end{array}$ & $\begin{array}{l}\text { 1998-2000: } 1 \text { year } \\
\text { 2001 onwards: } \\
\text { indefinite }\end{array}$ & $\begin{array}{l}\text { None } \\
\text { (before 2000: } \\
\text { changes caused } \\
\text { by major forces) }\end{array}$ & None & $\begin{array}{l}\text { Gov in } \\
\text { consultation } \\
\text { with CB }\end{array}$ & $\begin{array}{l}\text { Pub. of inflation report and } \\
\text { submission to Parliament. } \\
\text { Monthly announcement of } \\
\text { monetary policy direction. } \\
\text { Pub. of minutes of monetary } \\
\text { policy meetings }\end{array}$ \\
\hline
\end{tabular}




\section{Implementation and Design of Inflation Targeting in 19 Countries}

\begin{tabular}{|c|c|c|c|c|c|c|c|c|}
\hline Country & $\begin{array}{l}\text { Date } \\
\text { Introduced }\end{array}$ & $\begin{array}{l}\text { Target Price } \\
\text { Index }\end{array}$ & Target Width & Target Horizon & Escape Clauses & $\begin{array}{l}\text { Accountability of } \\
\text { Target Misses }\end{array}$ & Target set by & $\begin{array}{l}\text { Publications and } \\
\text { Accountability }\end{array}$ \\
\hline Mexico & Jan. 1999 & Headline CPI & $\begin{array}{l}\text { 1999: } 13 \% \\
\text { 2000: }<10 \% \\
2001: 6.5 \% \\
2002: 4.5 \% \\
\text { 2003: similar to } \\
\text { trade partners } \\
\text { inflation }(3 \%)\end{array}$ & $\begin{array}{l}\text { 1998-2002: 1 year } \\
\text { 2002 onwards: } \\
\text { indefinite }\end{array}$ & None & None & $\mathrm{CB}$ & Pub. of inflation report (2000) \\
\hline $\begin{array}{l}\text { New } \\
\text { Zealand }\end{array}$ & Mar. 1990 & $\begin{array}{l}\text { Headline CPI } \\
\text { (since 1999, } \\
\text { headline CPI } \\
\text { excludes interest } \\
\text { charges; prior to } \\
\text { then, targets } \\
\text { where defined in } \\
\text { terms of the } \\
\text { headline CPI } \\
\text { less interest } \\
\text { charges and } \\
\text { other first round } \\
\text { effect prices) }\end{array}$ & $\begin{array}{l}\text { 1990: } 3-5 \% \\
\text { 1991: } 2.5-4.5 \% \\
\text { 1992: } 1.5-3.5 \% \\
\text { 1993-1996: } 0-2 \% \\
\text { Since } 19970-3 \%\end{array}$ & $\begin{array}{l}\text { 1990-1992: 1 year } \\
\text { 1993-1996: multi- } \\
\text { year } \\
\text { Since 1997: indefinite }\end{array}$ & $\begin{array}{l}\text { Unusual events } \\
\text { provided they do } \\
\text { not cause general } \\
\text { inflationary } \\
\text { pressures }\end{array}$ & $\begin{array}{l}\text { Public explanation of } \\
\text { target breach and } \\
\text { measures taken (and } \\
\text { the time required) to } \\
\text { bring inflation within } \\
\text { the target. } \\
\text { Minister of Finance } \\
\text { may ask for } \\
\text { resignation of RBNZ } \\
\text { Governor }\end{array}$ & $\begin{array}{l}\text { Jointly by } \\
\text { Gov and CB }\end{array}$ & $\begin{array}{l}\text { Pub. of inflation report (1990). } \\
\text { Pub. of inflation projections }\end{array}$ \\
\hline Peru & Jan. 1994 & Headline CPI & $\begin{array}{l}\text { 1994: } 15-20 \% \\
\text { 1995: } 9-11 \% \\
\text { 1996: } 9.5-11.5 \% \\
\text { 1997: } 8-10 \% \\
\text { 1998: } 7.5-9 \% \\
\text { 1999: } 5-6 \% \\
\text { 2000: } 3.5-4 \% \\
\text { 2001: } 2.5-3.5 \% \\
\text { 2002: } 1.5-2.5 \% \\
2003: 1.5-2.5 \%\end{array}$ & 1 year & None & None & $\begin{array}{l}\mathrm{CB} \text { in } \\
\text { consultation } \\
\text { with Gov }\end{array}$ & None \\
\hline Poland & Oct. 1998 & Headline CPI & $\begin{array}{l}1998:<9.5 \% \\
1999: 6.6-7.8 \% \\
2000: 5.4-6.8 \% \\
2003:<4 \%\end{array}$ & $\begin{array}{l}\text { 1998-2000: } 1 \text { year } \\
\text { 2000-2003: multi- } \\
\text { year } \\
\text { 2003 onwards: } \\
\text { indefinite }\end{array}$ & None & None & $\mathrm{CB}$ & $\begin{array}{l}\text { Pub. of inflation report. } \\
\text { Pub. of inflation guidelines. } \\
\text { Pub. of Report on Monetary } \\
\text { Policy Implementation }\end{array}$ \\
\hline
\end{tabular}




\section{Implementation and Design of Inflation Targeting in 19 Countries}

\begin{tabular}{|c|c|c|c|c|c|c|c|c|}
\hline Country & $\begin{array}{l}\text { Date } \\
\text { Introduced }\end{array}$ & $\begin{array}{l}\text { Target Price } \\
\text { Index }\end{array}$ & Target Width & Target Horizon & Escape Clauses & $\begin{array}{l}\text { Accountability of } \\
\text { Target Misses }\end{array}$ & Target set by & $\begin{array}{l}\text { Publications and } \\
\text { Accountability }\end{array}$ \\
\hline $\begin{array}{l}\text { South } \\
\text { Africa }\end{array}$ & Feb. 2000 & $\begin{array}{l}\text { Core CPI } \\
\text { (excl. Interest } \\
\text { costs) }\end{array}$ & 2003: $3-6 \%$ & Multi-year & $\begin{array}{l}\text { Major unforseen } \\
\text { events outside } \mathrm{CB} \\
\text { control }\end{array}$ & None & $\mathrm{CB}$ & Pub. of inflation report \\
\hline Spain & $\begin{array}{l}\text { Nov. } 1994 \\
\text { to Jun. } 1998\end{array}$ & Headline CPI & $\begin{array}{l}\text { Jun. } 1996: 3.5-4 \% \\
\text { 1997: } 2.5 \% \\
\text { 1998: } 2 \%\end{array}$ & $\begin{array}{l}\text { Until 1996: multi- } \\
\text { year } \\
\text { 1997-1998: } 1 \text { year }\end{array}$ & None & None & $\mathrm{CB}$ & $\begin{array}{l}\text { Governor reports regularly to } \\
\text { Parliament. } \\
\text { Pub. of inflation report (1995) }\end{array}$ \\
\hline Sweden & Jan. 1993 & Headline CPI & $\begin{array}{l}\text { Since } 1995: 2 \% \\
( \pm 1 \%)\end{array}$ & $\begin{array}{l}\text { Until 1995: multi- } \\
\text { year } \\
\text { Since 1996: indefinite }\end{array}$ & None & None & $\mathrm{CB}$ & $\begin{array}{l}\text { Pub. of inflation report (1997). } \\
\text { Pub of minutes of monetary } \\
\text { policy meetings. } \\
\text { Pub. of inflation projections (2- } \\
\text { year fan chart). } \\
\text { Submission of monetary policy } \\
\text { report to Parliament }\end{array}$ \\
\hline Switzerland & Jan. 2000 & Headline CPI & $<2 \%$ & 3 years & $\begin{array}{l}\text { Unusual events } \\
\text { provided they do } \\
\text { not cause general } \\
\text { inflationary } \\
\text { pressures }\end{array}$ & None & $\mathrm{CB}$ & $\begin{array}{l}\text { Pub. of inflation report. } \\
\text { Pub. of inflation projections ( } 3 \\
\text { years) }\end{array}$ \\
\hline Thailand & Apr. 2000 & $\begin{array}{l}\text { Core CPI } \\
\text { (excl. raw } \\
\text { food and } \\
\text { energy prices) }\end{array}$ & 2000: $0-3.5 \%$. & Indefinite & None & $\begin{array}{l}\text { Public explanation of } \\
\text { target breach and } \\
\text { measures taken (and } \\
\text { the time required) to } \\
\text { bring inflation within } \\
\text { the target }\end{array}$ & $\begin{array}{l}\text { Gov in } \\
\text { consultation } \\
\text { with CB }\end{array}$ & $\begin{array}{l}\text { Pub. of inflation report ( } 2000) \text {. } \\
\text { Pub of inflation projections ( } 2- \\
\text { year fan chart). } \\
\text { Pub. of minutes of monetary } \\
\text { policy meetings }\end{array}$ \\
\hline $\begin{array}{l}\text { United } \\
\text { Kingdom }\end{array}$ & Oct. 1992 & $\begin{array}{l}\text { RPIX (excl. } \\
\text { mortgage } \\
\text { interest) }\end{array}$ & $\begin{array}{l}\text { 1992-1995: } 1-4 \% \\
\text { Since 1996: } 2.5 \%\end{array}$ & $\begin{array}{l}\text { Until 1995: multi- } \\
\text { year } \\
\text { Since 1996: indefinite }\end{array}$ & None & $\begin{array}{l}\text { Issuance of open } \\
\text { letter to the Minister } \\
\text { of Finance explaining } \\
\text { target breach and } \\
\text { measures taken (and } \\
\text { the time required) to } \\
\text { bring the inflation } \\
\text { within the target }\end{array}$ & Gov & $\begin{array}{l}\text { Pub. of inflation report. } \\
\text { Pub. of inflation projections (2- } \\
\text { year fan chart). } \\
\text { Pub. of models used for inflation } \\
\text { outlook }\end{array}$ \\
\hline
\end{tabular}

Sources: JP Morgan CB Watch, Country Sources., CB Web Pages, Schaechter et al. 
Table 3

Inflation Target Regime and Related Variables for 27 Countries (19901999): Descriptive Statistics and Simple Correlations for Cross-Section and Panel Samples

\begin{tabular}{|c|c|c|c|c|c|c|c|c|c|}
\hline \multicolumn{10}{|c|}{ Cross-Section Statistics } \\
\hline & $I T$ & Inf & Open & Fiscal & $B W$ & $M T$ & $C B F I$ & $C B G I$ & CBII \\
\hline Mean & 0.29 & 0.11 & 0.50 & -0.02 & 0.56 & 0.25 & 0.30 & 0.30 & 0.59 \\
\hline St. Dev. & 0.46 & 0.37 & 0.19 & 0.04 & 0.45 & 0.43 & 0.46 & 0.46 & 0.49 \\
\hline Max. & 1.00 & 5.55 & 0.85 & 0.06 & 1.00 & 1.00 & 1.00 & 1.00 & 1.00 \\
\hline Min. & 0.00 & 0.00 & 0.03 & -0.16 & 0.00 & 0.00 & 0.00 & 0.00 & 0.00 \\
\hline \multicolumn{10}{|c|}{ Panel Statistics } \\
\hline Mean & 1.00 & 0.97 & 0.85 & 0.06 & 1.00 & 1.00 & 1.00 & 1.00 & 1.00 \\
\hline St. Dev. & 0.00 & 0.00 & 0.03 & -0.16 & 0.00 & 0.00 & 0.00 & 0.00 & 0.00 \\
\hline Max. & 0.30 & 0.08 & 0.50 & -0.02 & 0.58 & 0.26 & 0.31 & 0.30 & 0.61 \\
\hline Min. & 0.46 & 0.15 & 0.19 & 0.04 & 0.45 & 0.44 & 0.46 & 0.46 & 0.49 \\
\hline \multicolumn{10}{|c|}{$\begin{array}{l}\text { Variable Correlations } \\
\text { Panel /Cross Section } \\
\end{array}$} \\
\hline Panel $\mid C S$ & $I T$ & Inf & Open & Fiscal & $B W$ & $M T$ & $C B F I$ & $C B G I$ & $C B I I$ \\
\hline$I T$ & 1.00 & -0.11 & 0.35 & 0.10 & 0.24 & -0.29 & -0.03 & -0.07 & 0.23 \\
\hline Inf & -0.20 & 1.00 & -0.10 & -0.17 & -0.01 & -0.04 & -0.10 & -0.12 & -0.18 \\
\hline Open & 0.25 & -0.42 & 1.00 & 0.16 & -0.08 & -0.13 & -0.11 & 0.08 & -0.03 \\
\hline Fiscal & 0.21 & -0.22 & 0.27 & 1.00 & -0.01 & 0.11 & 0.12 & 0.15 & 0.19 \\
\hline$B W$ & 0.02 & -0.07 & -0.32 & 0.16 & 1.00 & 0.08 & -0.01 & 0.01 & 0.14 \\
\hline$M T$ & -0.45 & 0.22 & 0.07 & 0.19 & 0.26 & 1.00 & 0.04 & 0.02 & -0.01 \\
\hline$C B F I$ & -0.22 & -0.08 & -0.09 & 0.25 & -0.22 & 0.09 & 1.00 & 0.68 & 0.51 \\
\hline$C B G I$ & -0.13 & -0.23 & -0.01 & 0.22 & -0.35 & -0.18 & 0.79 & 1.00 & 0.50 \\
\hline CBII & 0.30 & -0.15 & 0.18 & 0.35 & -0.06 & -0.03 & 0.40 & 0.52 & 1.00 \\
\hline
\end{tabular}

Note: The panel sample is comprised by 10 yeras of data (1990-99) for each of the 27 countries defined in Table 1. Panel (cross-section) sample correlations are reported in the upper (lower)-half matrix triangle. Standard errors are 0.06 (panel) and 0.19 (cross section). 


\section{Table 4}

\section{Empirical Results for the Likelihood of Having an IT Regime in Place (Probit Regressions for 1990-1999 Cross-Country Sample)}

\begin{tabular}{|c|c|c|c|c|c|c|}
\hline & \multicolumn{2}{|c|}{$\begin{array}{l}\text { Full Sample } \\
\text { (27 countries) }\end{array}$} & \multicolumn{2}{|c|}{$\begin{array}{c}\text { Restricted Sample } 1 \\
\text { ( } 24 \text { countries) }\end{array}$} & \multicolumn{2}{|c|}{$\begin{array}{c}\text { Restricted Sample } 2 \\
\text { ( } 24 \text { countries) }\end{array}$} \\
\hline & (1) & (2) & (3) & (4) & (5) & (6) \\
\hline Cons. & $\begin{array}{c}-9.7 \\
(8.2)\end{array}$ & $\begin{array}{c}-5.8 \\
(2.2)\end{array}$ & $\begin{array}{r}-13.4 \\
(7.5)\end{array}$ & $\begin{array}{c}-5.7 \\
(2.0)\end{array}$ & $\begin{array}{l}-12.5 \\
(8.2)\end{array}$ & $\begin{array}{c}-4.7 \\
(2.1)\end{array}$ \\
\hline Inf & $\begin{array}{r}45.2 \\
(25.2)\end{array}$ & $\begin{array}{r}33.6 \\
(12.3)\end{array}$ & $\begin{array}{r}69.2 \\
(28.5)\end{array}$ & $\begin{array}{r}43.7 \\
(13.5)\end{array}$ & $\begin{array}{r}69.1 \\
(27.8)\end{array}$ & $\begin{array}{r}46.9 \\
(15.7)\end{array}$ \\
\hline Open & $\begin{array}{l}11.5 \\
(6.7)\end{array}$ & $\begin{array}{r}7.6 \\
(3.0)\end{array}$ & $\begin{array}{l}11.4 \\
(5.0)\end{array}$ & $\begin{array}{r}7.1 \\
(2.7)\end{array}$ & $\begin{array}{c}10.5 \\
(6.0)\end{array}$ & $\begin{array}{r}5.3 \\
(3.1)\end{array}$ \\
\hline Fiscal & $\begin{array}{r}-20.4 \\
(45.1)\end{array}$ & & $\begin{array}{r}-49.7 \\
(45.7)\end{array}$ & & $\begin{array}{r}-46.7 \\
(46.8)\end{array}$ & \\
\hline$B W$ & $\begin{array}{r}0.3 \\
(3.0)\end{array}$ & & $\begin{array}{r}3.4 \\
(3.2)\end{array}$ & & $\begin{array}{r}3.2 \\
(3.3)\end{array}$ & \\
\hline$M T$ & $\begin{array}{r}-12.9 \\
(5.7)\end{array}$ & $\begin{array}{c}-9.3 \\
(3.0)\end{array}$ & $\begin{array}{r}-13.4 \\
(4.3)\end{array}$ & $\begin{array}{c}-9.6 \\
(2.8)\end{array}$ & $\begin{array}{r}-12.5 \\
(5.3)\end{array}$ & $\begin{array}{c}-7.9 \\
(3.0)\end{array}$ \\
\hline CBFI & $\begin{array}{r}2.2 \\
(1.9)\end{array}$ & & $\begin{array}{r}1.3 \\
(1.7)\end{array}$ & & $\begin{array}{r}1.0 \\
(2.0)\end{array}$ & \\
\hline$C B G I$ & $\begin{array}{r}-14.7 \\
(5.4)\end{array}$ & $\begin{array}{c}-9.6 \\
(3.2)\end{array}$ & $\begin{array}{r}-11.3 \\
(2.6)\end{array}$ & $\begin{array}{c}-9.8 \\
(2.8)\end{array}$ & $\begin{array}{r}-10.5 \\
(3.8)\end{array}$ & $\begin{array}{c}-8.2 \\
(3.1)\end{array}$ \\
\hline CBII & $\begin{array}{l}12.0 \\
(6.0)\end{array}$ & $\begin{array}{r}8.5 \\
(2.7)\end{array}$ & $\begin{array}{l}11.9 \\
(4.2)\end{array}$ & $\begin{array}{r}8.4 \\
(2.3)\end{array}$ & $\begin{array}{c}11.0 \\
(5.1)\end{array}$ & $\begin{array}{r}6.7 \\
(2.7)\end{array}$ \\
\hline Number of obs. & 27 & 27 & 24 & 24 & 24 & 24 \\
\hline Wald chi(2) & 9.8 & 10.8 & 23.0 & 13.7 & 18.3 & 11.9 \\
\hline Pseudo $\mathrm{R}^{2}$ & 0.61 & 0.57 & 0.63 & 0.57 & 0.63 & 0.58 \\
\hline
\end{tabular}

Note: Standard errors for the full and restricted samples are reported in parentheses.

Restricted sample 1 excludes three countries with very high inflation in the early 1990s (Brazil, Peru, and Poland). Restricted sample 2 excludes three countries that may not be classified as inflation targeters (Peru, Colombia, and Korea). 